\author{
H. V. Hryhoriv, D. A. Lega, L. A. Shemchuk
}

National University of Pharmacy of the Ministry of Health of Ukraine, Ukraine

53, Pushkinska str., Kharkiv, 61002. E-mail: legus.211288@gmail.com

\title{
1,2-Benzoxathiin-4(3H)-one 2,2-dioxide - an underinvestigated building block with a high synthetic and pharmacological potential: synthesis, chemical properties, biological activity
}

Aim. To analyze the available literature data on the methods of synthesis, chemical transformations and the biological activity of derivatives containing a sultone core - 1,2-benzoxathiin-4(3H)-one 2,2-dioxide - and to show the possibilities of their further use in the construction of new molecular systems with attractive pharmacological properties.

Results and discussion. The most widespread method for the synthesis of 1,2-benzoxathiin-4(3H)-one 2,2-dioxides is the cyclization of salicylic acid derivatives. The known chemical transformations of 1,2-benzoxathiin$4(3 \mathrm{H})$-one 2,2-dioxides deal with all reaction centers of the heterocyclic fragment of the condensed system $-\mathrm{C}=\mathrm{O}$ and $\mathrm{CH}_{2}$ groups, $\mathrm{SO}_{2}-\mathrm{O}$ bond, $\mathrm{CH}_{2} \mathrm{CO}$ fragment as a whole. It should be noted that the oxathiine nucleus is prone to undergo recyclizations. The use of 1,2-benzoxathiin-4(3H)-one 2,2-dioxides in multicomponent transformations still remains hardly explored. The "abnormal" course of some classical transformations involving 1,2-benzoxathiine 2,2-dioxides is also noteworthy. The study of the pharmacological properties of 1,2-benzoxathiin-4(3H)-one 2,2-dioxide derivatives is scarce and mainly based on their structural similarity to the coumarin core, which led to the study of anticoagulant, antimicrobial and antitumor properties for the sultone derivatives.

Conclusions. The analysis has shown a limited number of studies in each aspect - approaches to the synthesis of 1,2-benzoxathiin-4(3H)-one 2,2-dioxides, their chemical transformations and the study of their pharmacological activity. In addition to a small number of publications on this heterocyclic system, there have been almost no sultone studies in the last 20 years. Taking this into account 1,2-benzoxathiin-4(3H)-one 2,2-dioxide and its derivatives deserve close attention as objects of research for experimental chemistry and pharmacology.

Key words: sultone; oxathiine; heterocyclization; active methylene ketones; biological activity

\section{Г. В. Григорів, Д. О. Лега, Л. А. Шемчук}

Національний фрармацевтичний університет Міністерства охорони здоров'я України, Україна

1,2-Бензоксатіїн-4(3Н)-он 2,2-діоксид - малодосліджений білдинг-блок

із високим синтетичним та фармакологічним потенціалом:

синтез, хімічні властивості, біологічна активність

Мета. Проаналізувати наявні літературні дані щодо методів синтезу, хімічних перетворень та біологічної активності похідних, які містять у своєму складі ядро сультону - 1,2-бензоксатіїн-4(3Н)-он 2,2-діоксиду та показати можливості їх подальшого використання у побудові нових молекулярних систем з привабливими фрармакологічними властивостями.

Результати та їх обговорення. Найбільш популярний метод для синтезу ядра 1,2-бензоксатіїн-4(3H)-он 2,2-діоксидів - циклізація похідних саліцилової кислоти. Відомі хімічні перетворення 1,2-бензоксатіїн-4(3H)он 2,2-діоксидів зачіпають усі реакційні центри гетероциклічного фррагмента конденсованої системи - C=O та $\mathrm{CH}_{2}$ групи, $\mathrm{SO}_{2}$-О зв'язок та $\mathrm{CH}_{2} \mathrm{CO}$ фрагмент у цілому. Варто зазначити, що оксатіїнове ядро схильне до рециклізаційних перетворень. Використання 1,2-бензоксатіїн-4(3H)-он 2,2-діоксидів у багатокомпонентних перетвореннях досі залишається майже не дослідженим. Також звертає на себе увагу «аномальний» перебіг деяких класичних перетворень за участю 1,2-бензоксатіїн 2,2-діоксидів. Дослідження фрармакологічних властивостей похідних 1,2-бензоксатіїн-4(3H)-он 2,2-діоксиду носить одиничний характер та базується на їх структурній схожості з ядром кумарину, що зумовило вивчення антикоагулянтних, протимікробних та протипухлинних властивостей для похідних цього сультону.

Висновки. Проведений аналіз засвідчив обмежену кількість досліджень щодо кожного аспекту - підходів до синтезу 1,2-бензоксатіїн-4(3Н)-он 2,2-діоксидів, вивчення їх хімічних перетворень та фрармакологічної активності. Окрім незначної кількості публікацій, де висвітлено особливості цієї гетероциклічної системи, останні 20 років майже немає робіт з досліджень сультону. 3 огляду на це, 1,2-бензоксатіїн-4(3H)-он 2,2-діоксид та його похідні заслуговують на пильну увагу як об'єкти дослідження для експериментальної хімії та фрармакології.

Ключові слова: сультон; оксатіїн; гетероциклізація; метиленактивні кетони; біологічна активність 


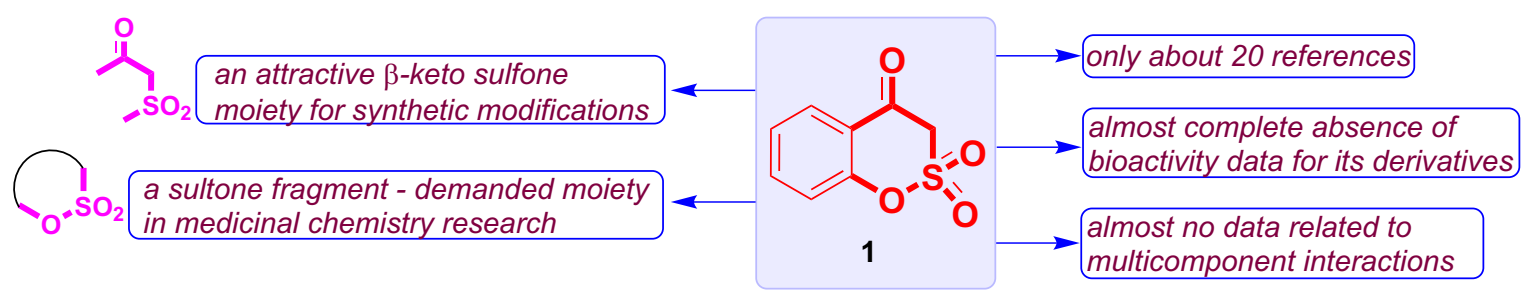

Fig. 1. The general structure and peculiarities of 1,2-benzoxathiin-4(3H)-one 2,2-dioxide (1)

Nowadays, organic chemistry deals with an incredible number of molecular platforms, and it is extremely difficult to find a relatively simple organic compound, which is underinvestigated with respect to its chemical and/or biological properties. Nevertheless, 1,2-benzoxathiin-4(3H)-one 2,2-dioxide (1) appeared to be one of such 'dark places' in organic chemistry (Fig. 1). To date, chemical databases provide only about 20 works concerning benzoxathiinone $\mathbf{1}$. Moreover, issues of the biological activity and multicomponent interactions for it have been hardly studied until now. Such a state of affairs is strange as compound $\mathbf{1}$ comprises two attractive structural moieties. The first one is a $\beta$-keto sulfone fragment that allows a molecule to be a versatile synthetic intermediate used for the preparation of diverse classes of organic compounds [1]. The second one is a sultone fragment, which is responsible for many kinds of pharmacological activities mainly concerned with their toxicological, skin sensitization, antiviral, carbonic anhydrase inhibitory properties, etc. [2-4]. Furthermore, in recent decades sultones have become valuable scaffolds widely used as building blocks in the field of medicinal chemistry and were described in several reviews $[5,6]$.

Besides, benzoxathiinone 1 may gain the additional value due to its isosteric relationships. At the beginning of the $\mathrm{XX}^{\text {th }}$ century the concept of isosterism became especially relevant in medical chemistry. It still remains a powerful tool for the purposeful search of new biologically active substances $[7,8]$. The isosteric replacement changes one or more characteristics of the molecule: size, shape, hydrophobicity, solubility, $\mathrm{pKa}$, reactivity. Such changes make it possible to increase the selectivity of the compound, reduce its side effects and toxicity, improve pharmacokinetic characteristics and increase the metabolic stability. From this point of view, 1,2-benzoxathiin-4(3H)-one 2,2-dioxide (1) core can be considered as isostere, first of all, to such a well-known pharmacophore as 4-hydroxycoumarin A (Fig. 2). Among the derivatives of the latter there are anticoagulants of the indirect action, vitamin K inhibitors - warfarin, dicoumarol and others [9]. Secondly, the structural analog of this compound is 1H-2,1-benzothiazin-4(3H)-one 2,2-dioxide $\mathbf{B}$, which derivatives have shown high efficacy in the treatment of pain and inflammation, and even greater activity compared to such known NSAIDs as Piroxicam ${ }^{\circledR}$ and Meloxicam $^{\circledR}[10,11]$.

This review focuses on developments in chemistry and pharmacology of 1,2-benzoxathiin-4(3H)-one 2,2dioxide (1) derivatives, including our achievements in this field. We hope the review will encourage, guide and intensify further research in the topic of sultone $\mathbf{1}$, resulting in a breakthrough in the search for new medicines.

\section{Results and discussion}

A lot of methods have been developed for the preparation of sultones. The classical approach to their synthesis is the intramolecular cyclization of aromatic
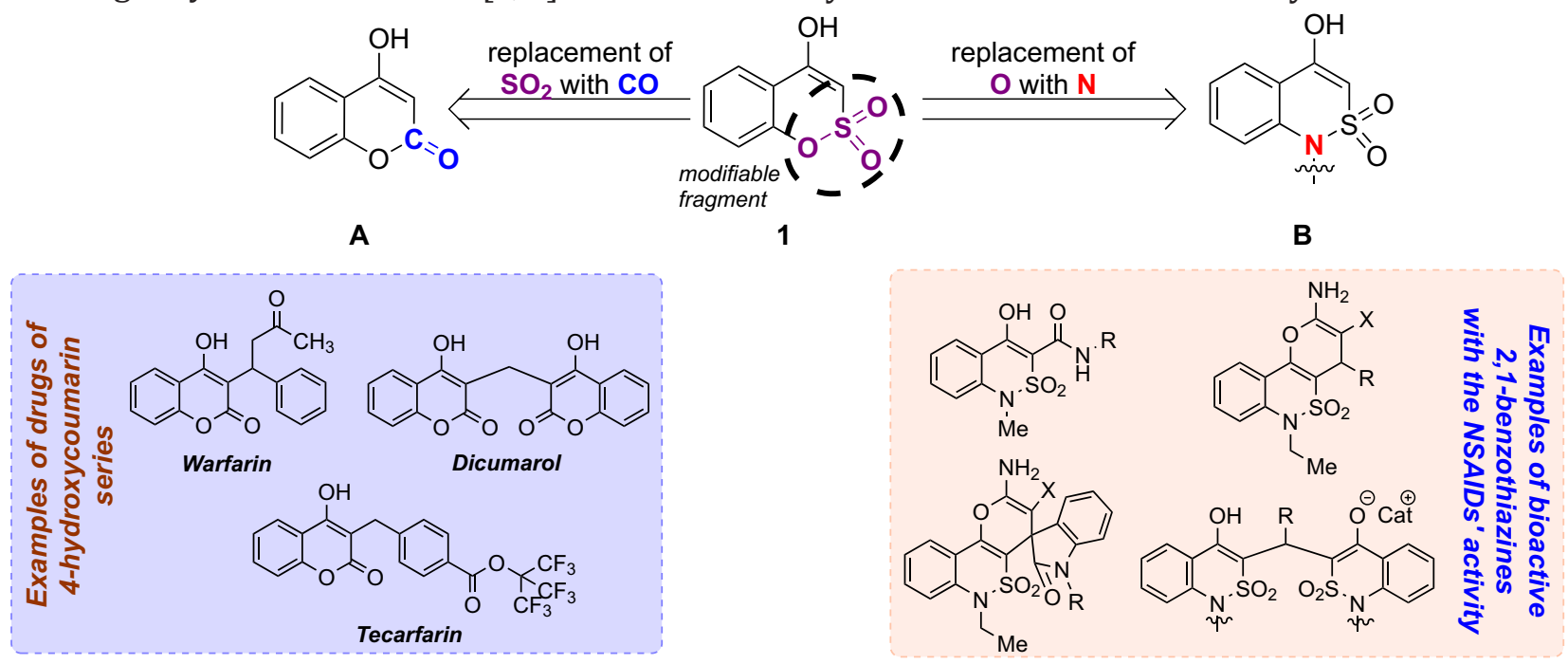

Fig. 2 Isosteric relationships of 1,2-benzoxathiin-4(3H)-one 2,2-dioxide (1) with 4-hydroxycoumarin $\mathbf{A}$ and $1 H$-2,1-benzothiazin-4(3H)-one 2,2-dioxide B 


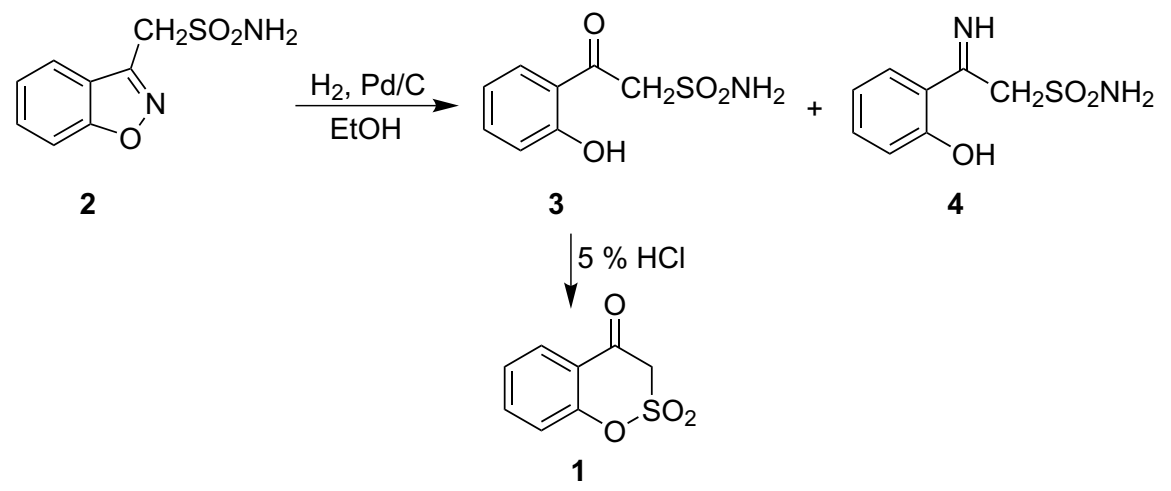

Scheme 1. Synthesis of sultone 1 based on 2-hydroxy-a-sulfamoylacetophenone (3)

hydroxysulfonic acids under the action of the concentrated sulfuric acid, phosphorus pentachloride or phosphorus oxychloride [12]. Other methods involve the intramolecular Diels-Alder reaction of vinyl sulfonates [13], sulfonate metathesis reactions $[14,15]$, the cyclization reactions of sulfonates using organometallic catalysts containing copper, palladium, rhodium, ruthenium, etc. $[12,16,17]$. According to these methods sultons with different cycle sizes, mono- and polycyclic, saturated, unsaturated and condensed with aromatic systems can be synthesized.

Regarding the approaches to the synthesis of sultone 1 some works describe the methods where it was not the targeted one or turned out to be an unexpected product of another interaction studied. An example of such transformations is the acidic hydrolysis of 2 -hydroxy- $\alpha$-sulfamoylacetophenone (3) presented by the authors Uno et al. [18]. In the process of the catalytic hydrogenation of 3-sulfamoylmethyl-1,2-benzisoxazole (2) two products were obtained: 2-hydroxy- $\alpha$-sulfamoylacetophenone (3) and its imine 4. While studying the chemical properties of the hydrogenated products the authors tried to hydrolyze the compound 3 . In the case of using $5 \%$ solution of hydro-

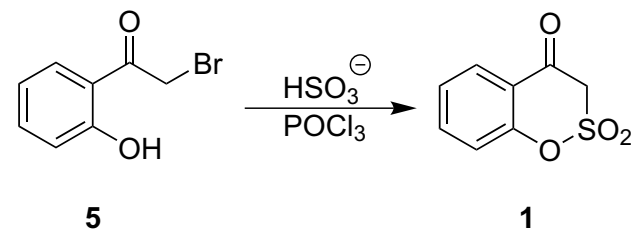

Scheme 2. Application of o-hydroxy-a-bromoacetophenone (5) in the synthesis of sultone 1 chloric acid an unexpected cyclic product was obtained - 1,2-benzoxathiin-4(3H)-one 2,2-dioxide (1) with the yield of $98 \%$ (Scheme 1).

A purposeful synthesis of this heterocyclic system was first described by King et al. [19] (Scheme 2). It was based on the interaction of $o$-hydroxy- $\alpha$-bromoacetophenone (5) with hydrosulfites in the presence of phosphorus oxychloride.

The method proposed by W. Berbiery et al. [20] was similar by its logic. Authors reported the synthesis of a group of stable, crystalline 1,2-benzoxathian4-one S-oxides 7 , which could be easily obtained by refluxing the corresponding hydroxy ketones with four parts of $\mathrm{SOCl}_{2}$ for $1 \mathrm{~h}$. The latter were oxidized by $\mathrm{H}_{2} \mathrm{O}_{2}$ to give the target benzoxathiinones $\mathbf{1}$. Another cyclizing agent used in the reaction with propiophenone 8 was chlorosulfonic acid [21]. A drawback of the approach is the formation of a mixture of the benzoxathiinone $\mathbf{1}$ and its $4-\mathrm{Cl}$ analog $\mathbf{9}$, which, however, can be easily separated (Scheme 3 ).

The papers [22, 23] presented a two-step synthesis of compound $\mathbf{1}$ by the cyclization of salicylic aldehyde methanesulfonates $\mathbf{1 0}$ followed by the oxidation of the product $\mathbf{1 1}$ formed. However, the total yield of sultone 1 in these approaches was low, only about $30 \%$ (Scheme 4). Compounds $\mathbf{1 0}$ can be easily obtained from the substituted salicylic aldehydes by their interaction with methanesulfonyl chloride $\left(\mathrm{Et}_{3} \mathrm{~N}, \mathrm{DCM}, \mathrm{r.t}\right.$.). It is worth commenting another way for modification of hydroxylated derivatives $\mathbf{1 1}$ into 1,2-benzoxathiine 2,2-dioxides $\mathbf{1 2}$ using $\mathrm{POCl}_{3} /$ pyridine mixture [24]. The latter gained great attention

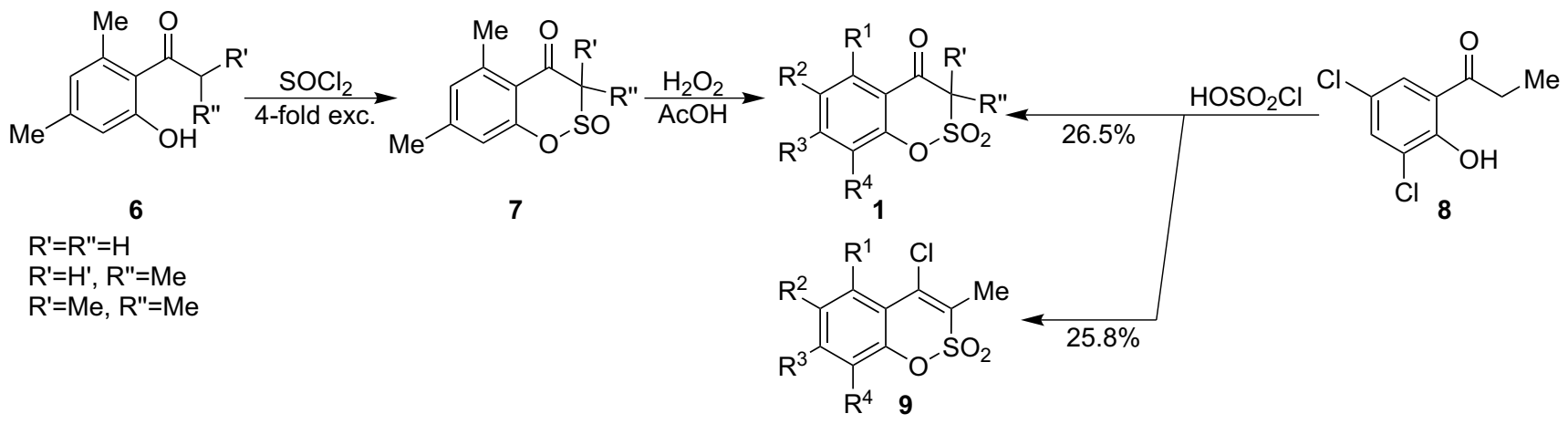

Scheme 3. Heterocyclizations of o-hydroxyphenylketones with thionyl chloride and chlorosulfonic acid in the synthesis of sultone 1 


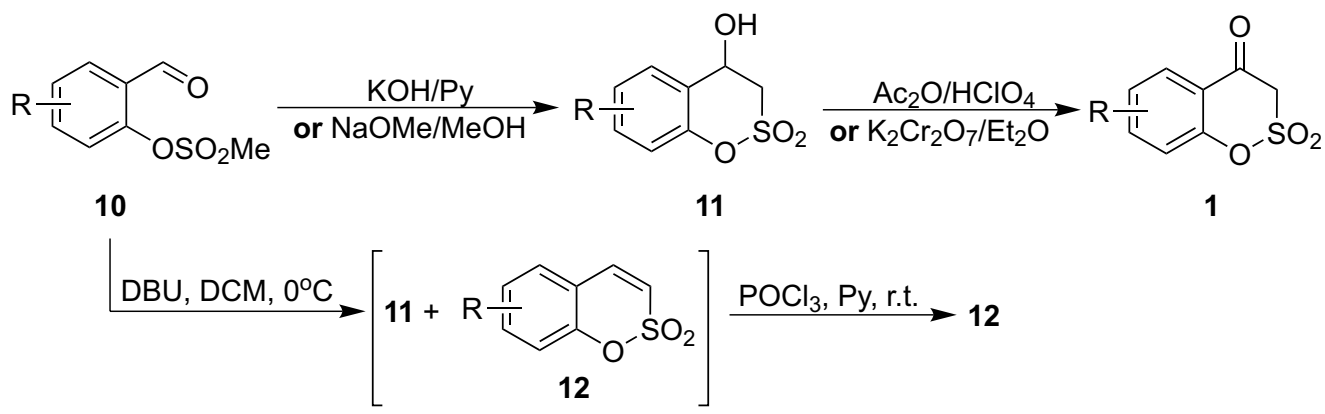

Scheme 4. Application of salicylic aldehyde methanesulfonates 10 in the synthesis of sultone 1

as a selective carbonic anhdydrase (CA) IX and XII inhibitors and can be successfully applied to the treatment of some cancer types [25-27].

Schwender et al. in 1978 patented a new way to the synthesis of 1,2-benzoxathiin-4(3H)-one 2,2-dioxide derivatives [28] (Scheme 5). According to it, methylsulfonates 14 were obtained by the interaction of the substituted methyl esters of salicylic acid $\mathbf{1 3}$ with methanesulfonyl chloride in the presence of a base. Further heterocyclization of the latter was carried out by its heating in DMF with sodium hydride leading to the formation of the target products 1 with a total yield of $59-76 \%$.

This approach has gained popularity and has been applied with a variety of conditions in other synthetic investigations [29-31]. For example, authors [29] performed the heterocyclization of methanesulfonate $\mathbf{1 4}$ by the action of sodium hydride when cooling and modifying the conditions of the product isolation. Arava et al. [30] used sodium hydride in DMSO for cyclization (the yield of compounds 1 ranged from 47 to $76 \%$ ). The reaction proceeded well with bromo-, chloro-, methoxy- and methyl-substituted derivatives 14; in the presence of the $\mathrm{NO}_{2}$-group the target derivatives 1 could not be obtained. The use of potassium tert-butoxide or 1,8-diazabicyclo[5.4.0] undec-7-ene (DBU) in THF for the phenyl ester $\mathbf{1 6}$ cyclization allowed to obtain 1,2-benzoxathiin-4(3H)one 2,2-dioxide (1) with the yield of 70\% [31] (Scheme 6).

A similar approach to 1,2-benzoxathiin-4(3H)one 2,2-dioxide derivatives was used in the study of Peixoto et al. [32]. The synthetic route to benzoxathiinone $\mathbf{1}$ is shown in Scheme 7. The authors used 2-methylresorcinol (17) as a starting material, which allowed obtaining 1 substituted in the benzene nucleus. After introduction of the aldehyde group into the 2-methylresorcinol molecule and its conversion into an ester, one of the hydroxyl groups was regioselectively protected with tetrahydropyran (THP). The free hydroxyl group reacted with methanesulfonyl chloride, and the resulting derivative $\mathbf{2 1}$ was cyclized by the action of sodium hydride in DMF. The tetrahydropyran protection was easily removed in the acidic medium to give 7-hydroxy-8-methyl-1,2benzoxathiin-4(3H)-one 2,2-dioxide (1).

According to the synthetic routes described above mostly 1,2-benzoxathiin-4(3H)-one 2,2-dioxide derivatives unsubstituted in position 3 of the sultone ring were obtained. Although the cyclization of acetophenones $\mathbf{6}$ and $\mathbf{8}$ is the way of introducing a substituent in position 3 of the oxathiine moiety, it is still unclear why various alkanesulfonyl chlorides are not used in the approach involving alkyl salicylates as starting reagents (Scheme 7).

Approaches to the synthesis of the benzoxathiinone heterocyclic system functionalized in position 3 are also described in the literature. These synthetic pathways were studied in detail by Löwe et al. As a starting material in a number of studies 3-chromonsulfonic acid chloride (25), which was obtained from the corresponding acid $\mathbf{2 3}$, was used [33] (Scheme 8).<smiles>[R14][14c]1ccc(O)c(C(C)=O)c1</smiles>

13

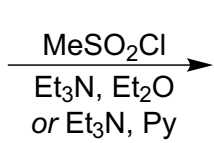
or $\mathrm{Et}_{3} \mathrm{~N}, \mathrm{Py}$<smiles>[R14][14c]1ccc(O[R6]([H])([O-])O)c(C(C)=O)c1</smiles>

14

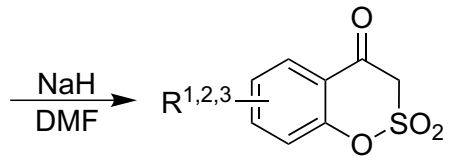

1

$\mathrm{R}^{1,2,3}=\mathrm{Br}, \mathrm{Ph}$

Scheme 5. The two-step synthesis of sultone 1 based on methyl salicylates 13

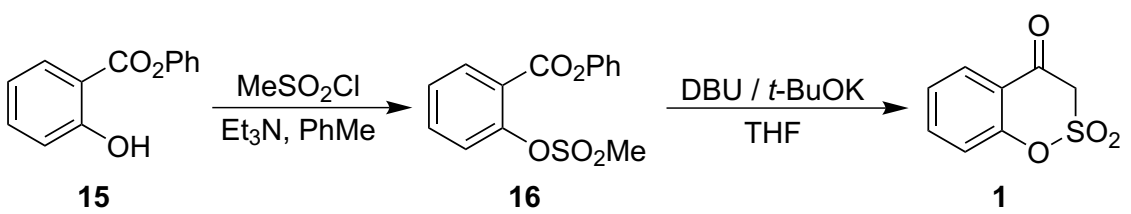

Scheme 6 . The two-step synthesis of sultone 1 based on phenyl salicylate (15) 

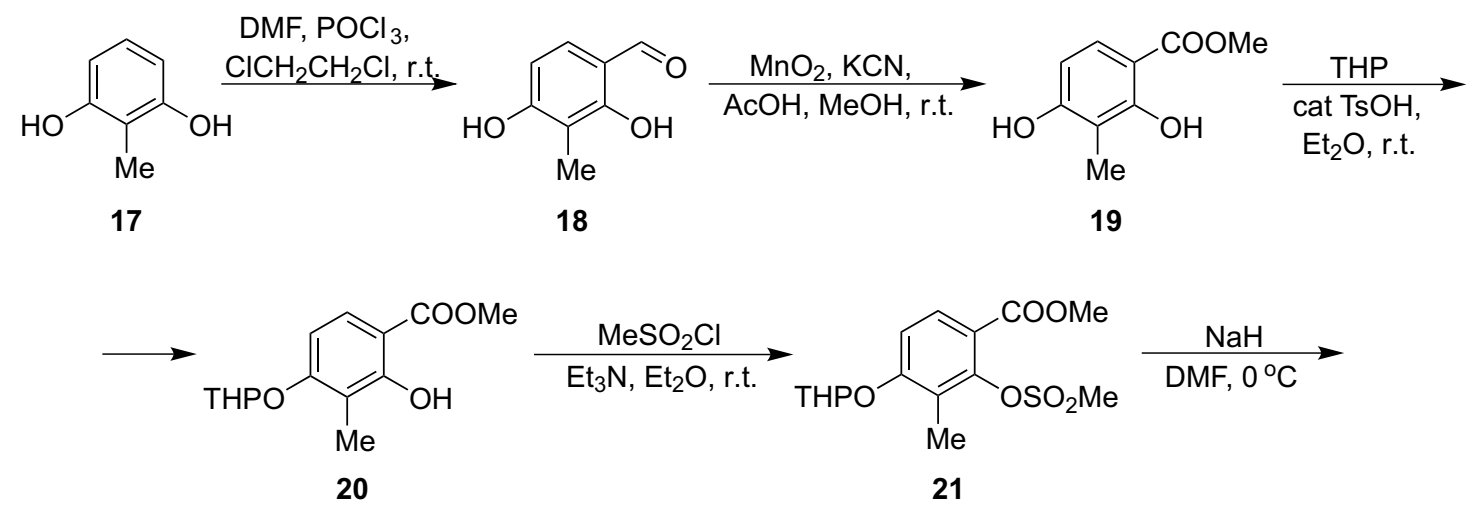

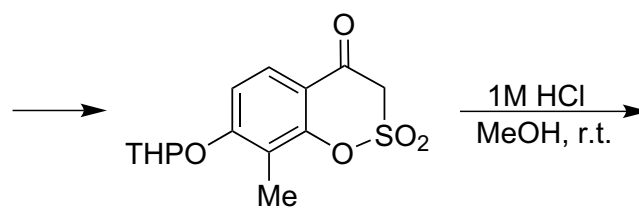

22<smiles>Cc1c(O)ccc2c1OS(=O)(=O)CC2=O</smiles>

1

Scheme 7. 2-Methylresorcinol (17) in the synthesis of sultone 1

The same authors found that the interaction of compound 25 with methylamine in ethanol at room temperature resulted in the formation of an unexpected enaminoketone - a derivative of benzoxathiinone 26 [33] (Scheme 9). The course of the transformation $\mathbf{2 5} \rightarrow \mathbf{2 6}$ was explained by the authors as an ANRORC mechanism accompanied by the opening of the pyran cycle as the result of the nucleophilic addition of methylamine (intermediate 27) and the subsequent ring closure with the sultone nucleus formation.
As it was shown in the latter study [34], the fusion of compound $\mathbf{2 5}$ with ammonium acetate led to the $\mathrm{N}$-unsubstituted enaminone $\mathbf{2 8}$ apparently formed by the same ANRORC way (Scheme 9). Enaminoketone 26 exhibits properties typical for enamines and can be hydrolyzed to aldehyde 29 . The latter exists in the form of at least 2 tautomers $29 \mathrm{~A}$ and $29 \mathrm{~B}$ as it was confirmed by ${ }^{1} \mathrm{H}$ NMR spectroscopy data.

As a continuation of these studies Löwe et al. used the synthetic equivalent of sulfonyl chloride $\mathbf{2 5}$ - a phenyl<smiles>O=c1c(S(=O)(=O)O)coc2ccccc12</smiles>

23<smiles>CCO[N+](=O)[O-]</smiles>

24<smiles>O=c1c(S(=O)(=O)Cl)coc2ccccc12</smiles>

25

Scheme 8. The preparation of 3-chromonsulfonic acid chloride (25) - a starting compound in the synthesis of 3-substituted sultones 1

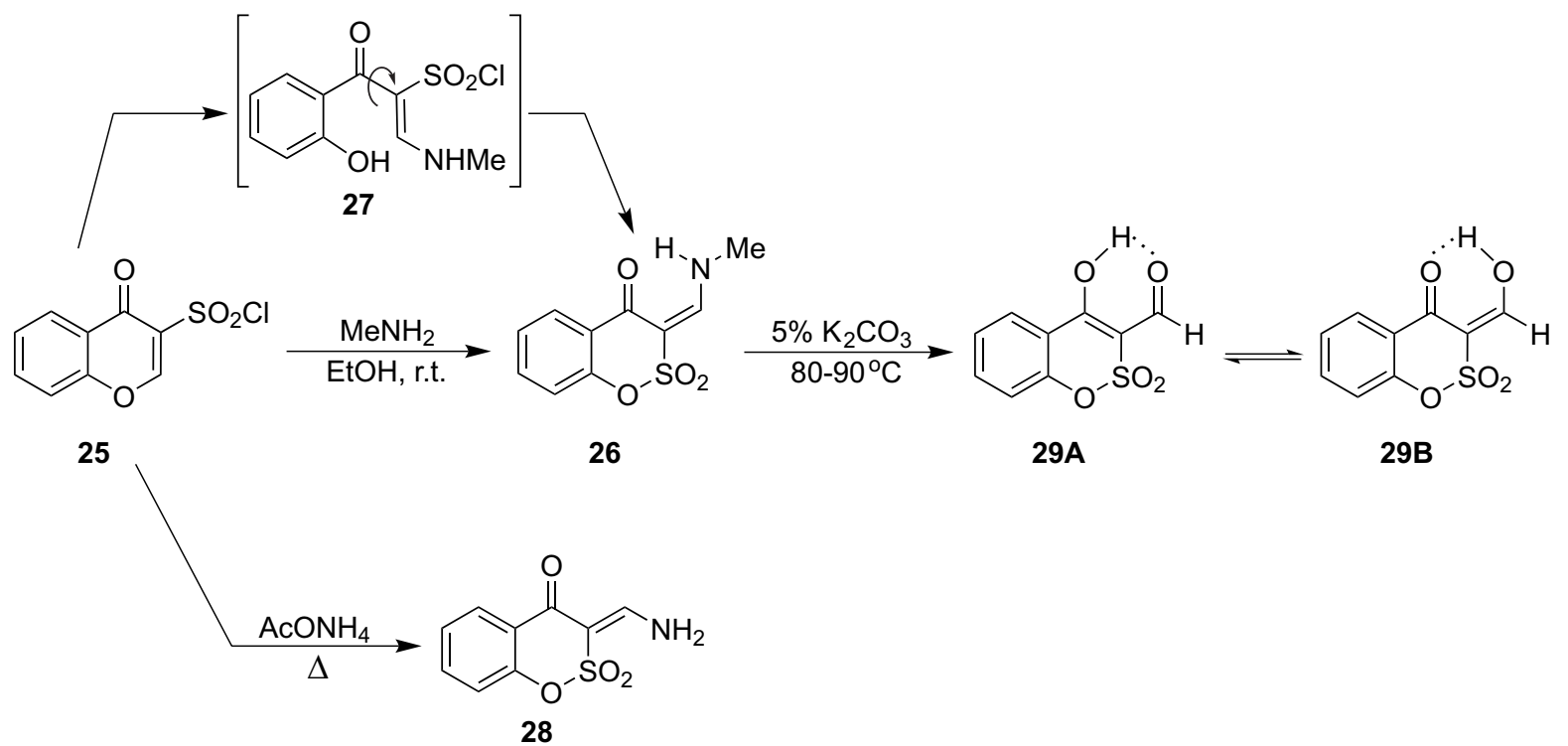


<smiles>Cc1ccc2occ(S(=O)(=O)Oc3ccccc3)c(=O)c2c1</smiles>

30

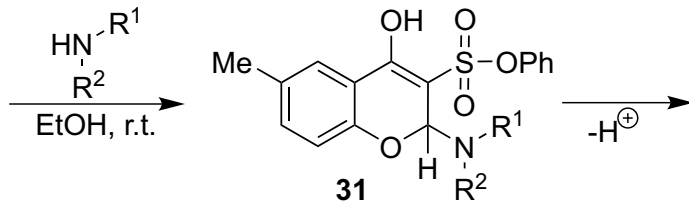

31

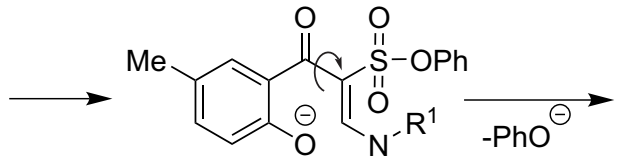

32

$\mathrm{R}^{2}$<smiles>[R]N/C=C1/C(=O)c2cc(C)ccc2OS1(=O)=O</smiles>

33

Scheme 10. The recyclization of 3-chromonsulfonic acid phenyl ester (30) with amines

ester 30, and studied its interaction with a series of primary and secondary amines [35] (Scheme 10). The reaction proceeded with the formation of enaminoketones $\mathbf{3 3}$ by the addition-elimination mechanism similar to the case of sulfonyl chloride 25 . Also, similarly to sulfonyl chloride $\mathbf{2 5}$, the fusion of phenyl ester $\mathbf{3 0}$ with ammonium acetate resulted in compound 28 [36].

In order to obtain enaminoketones with the structure similar to 33 , another way was proposed. It consisted in the interaction of aromatic enaminones $\mathbf{3 4}$ with chlorosulfonic acid [37]. The result of this interaction was influenced by the temperature mode applied to it. Thus, at room temperature sulfochlorination was proceeding on the benzene ring giving derivative 35 (Scheme 11). When the mixture was heated to $150^{\circ} \mathrm{C}$, two equivalents of chlorosulfonic acid were involved in the reaction so that one of them reacted with the benzene fragment, and another bridged $\mathrm{OH}$ and enaminone substituents of the benzene ring producing 1,2-benzoxathiin-4(3H)-one 2,2-dioxides 36 . The reaction of compound $36\left(\mathrm{R}^{1}=\mathrm{H}\right)$ with ammonia gave the corresponding sulfonamide $\mathbf{3 7}$, while chloro-substituted derivative $\mathbf{3 6}\left(\mathrm{R}^{1}=\mathrm{Cl}\right)$ was surprisingly inert in this reaction, and the formation of the sulfonamide was not observed.

Along with the results of Löwe, W. Berbiery [20] and R. Meyer [21] the synthesis of 3-substituted derivatives of 1,2-benzoxathine 2,2-dioxide is also presented in a number of studies carried out by Ghandi et al. Their paper [38] provide an easy-performed one-pot interaction of the substituted 2-hydroxybenzaldehydes 38 with the 4-substituted 2-phenylethenesulfonyl chlorides 39 in DMF in the presence of DBU that led to the formation of benzylbenzo[ $e][1,2]$ oxathiin4(3H)-one 2,2-dioxides 41 (Scheme 12). Scientists also managed to isolate the intermediates - 2-formylphenyl-2-phenylethnesulfonates $\mathbf{4 0}$ and to investigate the effect of the solvent on the cyclization process. In the case of DBU and DMF the above-mentioned sultons were formed. The replacement of DMF with methanol gave 3-(methoxyphenylmethyl)benzo[e][1,2]oxathiine 2,2-dioxides 42 . The authors suggested that the formation of $\mathbf{4 1}$ and $\mathbf{4 2}$ proceeded via the DBU-catalyzed $O$-sulfonylation/intramolecular BaylisHillman/1,3-H shift or dehydration tandem sequences, respectively.

Based on the experimental data and the results previously published the authors proposed the mechanisms for the DBU-catalyzed intramolecular BaylisHillman reaction described. It is illustrated in Scheme 13. For 41, the in situ generated $\mathbf{4 0}$ undergoes the nucleophilic addition of DBU giving the zwitter-ion $\mathbf{A}$. The subsequent nucleophilic addition of $\mathbf{A}$ to the aldehyde group affords the intermediate $\mathbf{B}$. The generated hydroxy-derivative $\mathbf{C}$ in the next step is transformed into the final ketone $\mathbf{4 1}$ by the DBU-catalyzed 1,3-H shift. For 42, the in situ generated methoxide<smiles>[R]c1ccc(C(=O)/C=C/N(C)N(C)C)c(O)c1</smiles>

Scheme 11. The synthesis of sultone 37 involving heterocyclization of aromatic enaminones 34 


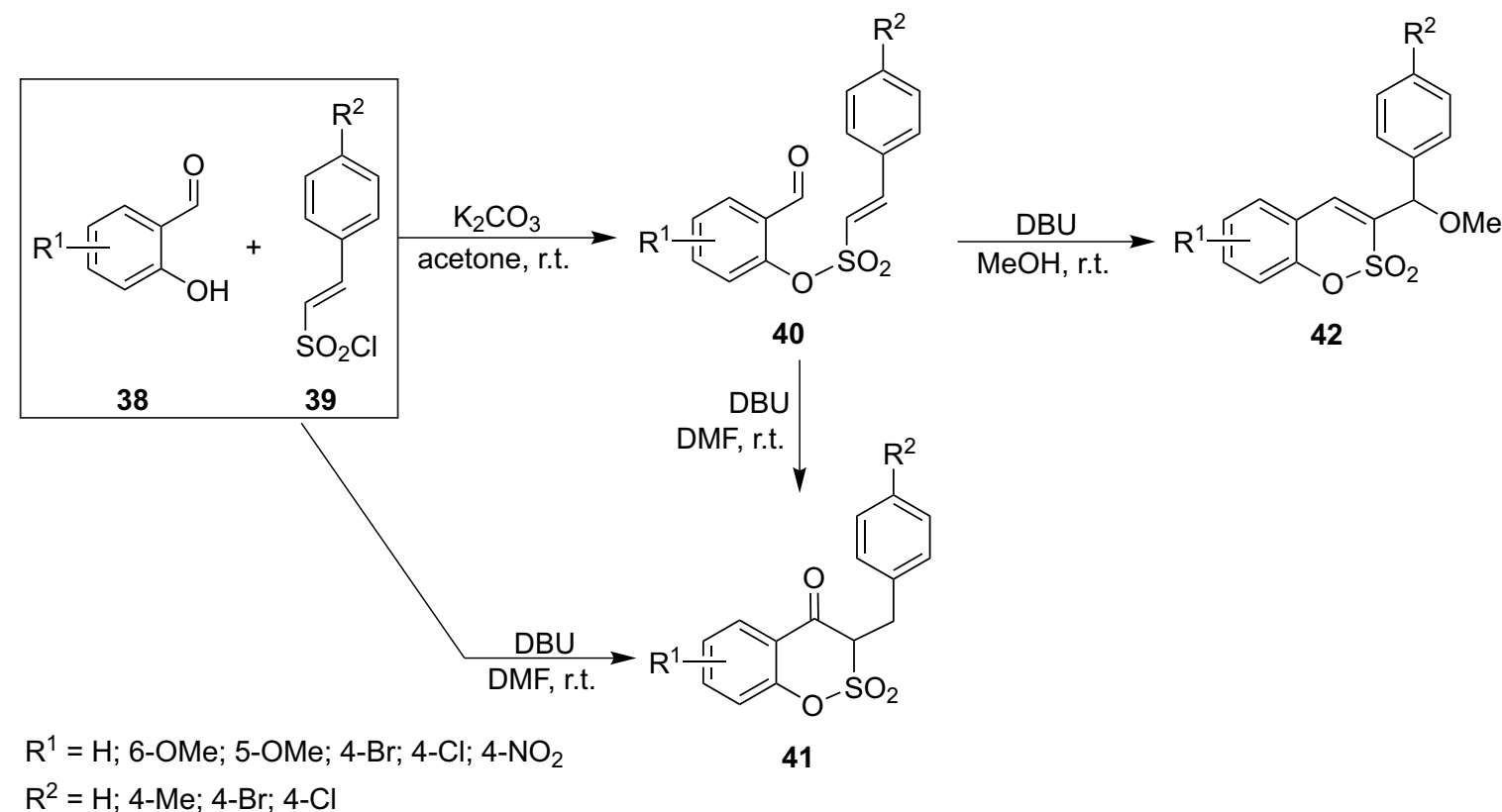

Scheme 12. The synthesis of sultone $\mathbf{4 1}$ based on DBU-catalyzed O-sulfonylation/intramolecular Baylis-Hillman/1,3-H shift tandem sequence

anion promotes the intramolecular Baylis-Hillman reaction, affording intermediates $\mathbf{E}$ and $\mathbf{F}$. The latter is easily transformed into $\mathbf{4 2}$ through losing a hydroxide-anion.

Continuing the previous studies Ghandi et al. proposed a strategy for the one-pot synthesis of biolo- gically interesting pentacyclic condensed 1,2-benzoxathiine 2,2-dioxide derivatives. It consisted in the interaction of the substituted 2-hydroxybenzaldehydes 38, 2-phenylethylene sulfonyl chloride (39) and 4-hydroxycoumarins $\mathbf{4 3}$ or 4-hydroxyquinoline (44) in the presence of ethylenediamine- $\mathrm{N}, \mathrm{N}^{\prime}$-diacetic

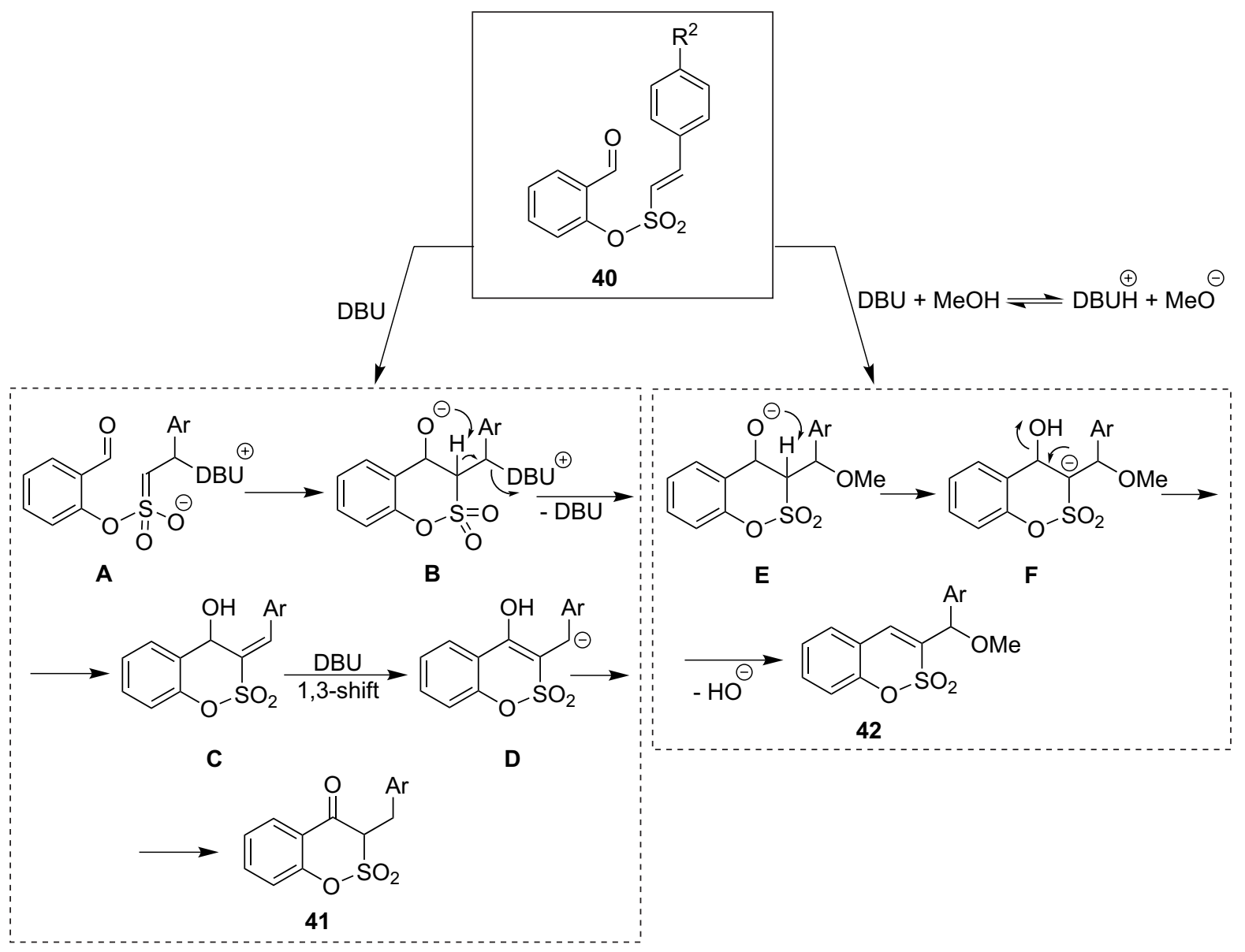

Scheme 13. The mechanisms of products $\mathbf{4 1}$ and $\mathbf{4 2}$ formation 


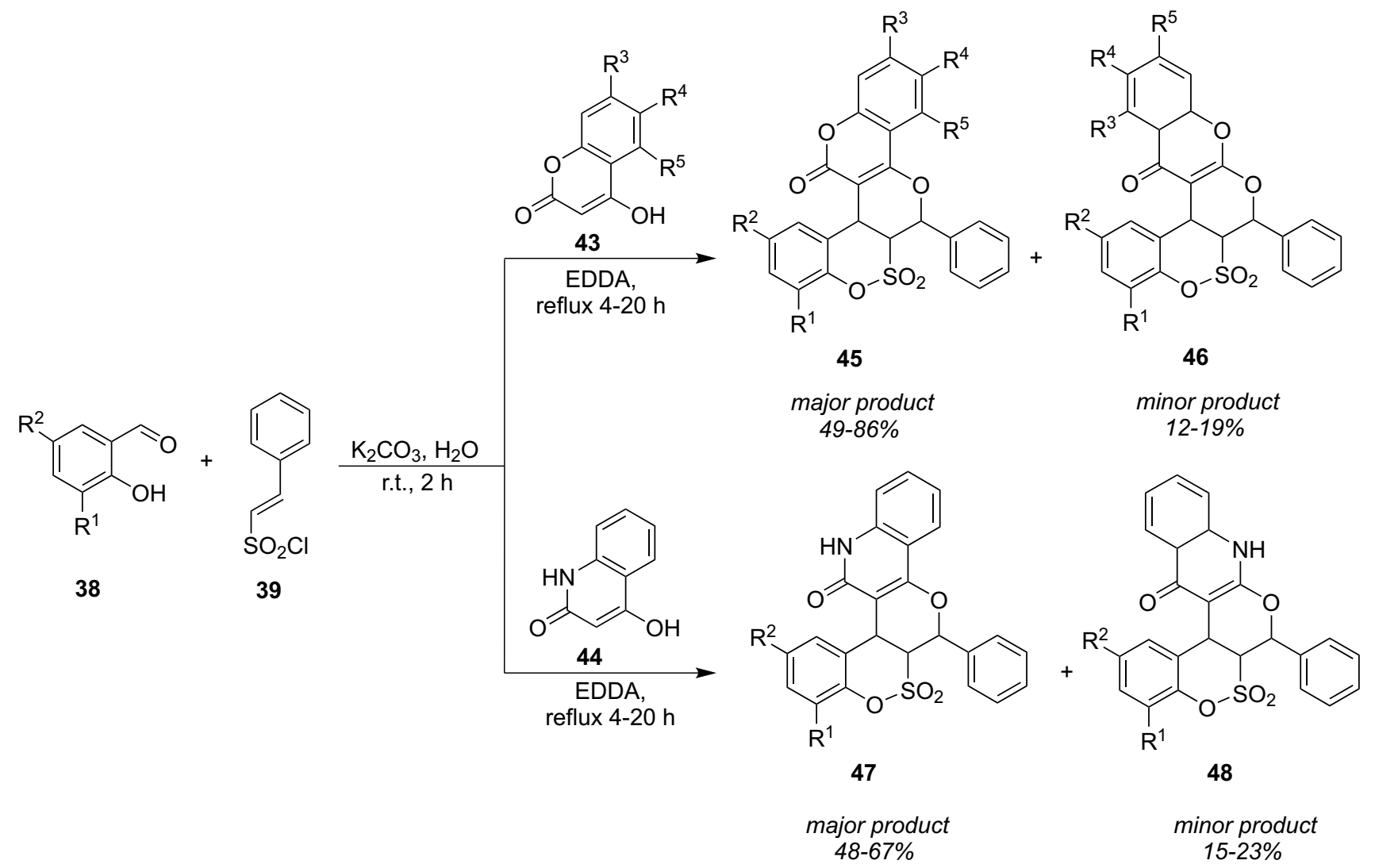

Scheme 14. The one-pot synthesis of the pentacyclic condensed 1,2-benzoxathiine 2,2-dioxide derivatives $45-\mathbf{4 8}$

acid (EDDA) [39] (Scheme 14). The interaction presumably proceeded through the $O$-sulfonylation/Knoevenagel condensation/hetero-Diels-Alder reaction cascade and resulted in derivatives 45-48. It should be noted that the interaction at the stage of the heteroDiels-Alder reaction was non-regioselective with the participation of oxygens of the heterodiene system in the positions 2 and 4.

The reactivity of 1,2-benzoxathiin-4(3H)-one 2,2dioxide (1) is connected with the presence of a carbonyl group, an activated methylene group and an endocyclic S-O bond in its structure. It is worth noting that the direct introduction of substituents in the benzene ring of 1,2-benzoxathiin-4(3H)-one 2,2-dioxides has not been found in the literature. As it was shown above, the corresponding substituted starting compounds were used for the synthesis of the benzene-substituted derivatives.

The carbonyl group of 1,2-benzoxathiin-4(3H)-one 2,2-dioxide (1) exhibits the chemical properties of ketones, but currently there are only a few studies in this area. Arava etal. [30] showed the possibility of converting 1 to oximes 49. The latter under the action of alkoxides undergo recyclization with the formation of 1,2benzisoxazole-3-methanesulfonates $\mathbf{5 0}$, which are important intermediates for the preparation of an anticonvulsant zonisamide (Scheme 15).

Another example of the 1,2-benzoxathiin-4(3H)one 2,2-dioxide carbonyl group modification is the preparation of enamines. The authors [28] found conditions for the interaction of compound 1 with piperidine (51), which led to the formation of 4-(1-piperidinyl)benzoxathiine 2,2-dioxide (52) with the yield of $76 \%$ (Scheme 16). Considering the fact that in medicinal chemistry sultons are known because of their anti-inflammatory effects [40] the authors of the current work studied and revealed the anti-inflammatory properties of $\mathbf{5 2}$, which reduced carrageenan edema when administered intraperitoneally to rats $(100 \mathrm{mg} / \mathrm{kg})$.

According to the literature data, the vast majority of chemical transformations known for 1,2-benzoxathiin-4(3H)-one 2,2-dioxide (1) occurs with the participation of a methylene group, which increased<smiles>[R]c1ccc2c(c1)O[Sb](=O)(O)CC2=O</smiles>

$\mathrm{R}=5-\mathrm{Br}, 5-\mathrm{Cl}, 3,5-\mathrm{diCl}, 3,5-\mathrm{diBr}, 3-\mathrm{OMe}, 4-\mathrm{OMe}, 5-\mathrm{OMe}, 4-\mathrm{Me}$ 


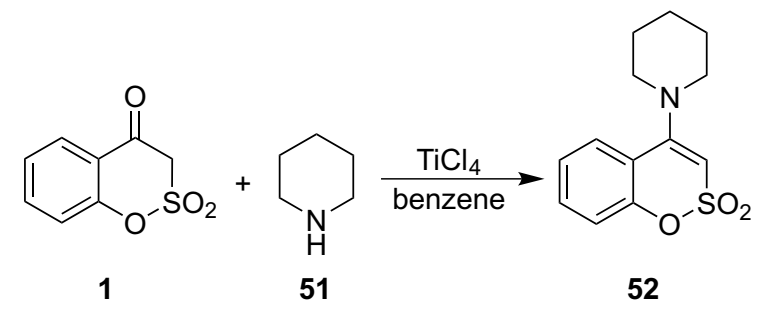

Scheme 16. The preparation of enamines based on sultone 1

reactivity is due to the presence of the neighboring $\mathrm{C}=\mathrm{O}$ and $\mathrm{SO}_{2}$-fragments. Mobility of the $\mathrm{CH}_{2}$ moiety hydrogens results in the keto-enol tautomerism of sultone 1 , which can be easily observed in its ${ }^{1} \mathrm{H}$ NMR spectrum (Fig. 3). Therefore, 1,2-benzoxathiin-4(3H)-one 2,2-dioxide (1) can be used for synthetic purposes as an enolnucleophile.

Using this property Schwender et al. proposed an approach to the functionalization of compound $\mathbf{1}$ in position 3, which consisted in its interaction with substituted isocyanates in DMF in the presence of sodium hydride with the formation of amides $\mathbf{5 3}$ (Scheme 17) [28].

In the study on the development of medicines coumarin antibiotics, inhibitors of bacterial DNA gyrase Peixoto et al. [32] proposed to perform a bioisosteric substitution, namely to replace the coumarin carbonyl group with more polar $\mathrm{SO}_{2}$, expecting that this would increase the ability of the compound to inhibit the enzyme. In addition, the high polarity of the sulfone moiety was to provide better water solubility of the compounds synthesized. For this purpose, glycosides with noviose sugar $\mathbf{5 4}$ and $\mathbf{5 5}$ (Scheme 18) were synthesized; they were further functionalized by the active methylene group of 1,2-benzoxathiin$4(3 \mathrm{H})$-one 2,2-dioxide nucleus.

Compound $\mathbf{5 4}$ was obtained by the coupling of 1 with the activated noviose carbonate under $\mathrm{BF}_{3}-\mathrm{Et}_{2} \mathrm{O}$ conditions. Derivative 55 was prepared by Mitsunobu's coupling between pyrrole-containing noviose and sultone 1 (Scheme 18).<smiles>[R]NC(=O)C1=C(O)c2ccc([N+](=O)[O-])cc2O[Sb]1(=O)=O</smiles>

Scheme 17. The interaction of sultone 1 with isocyanates

Modification of the position 3 of $\mathbf{5 4}$ was performed by its interaction with 3-chlorophenylisocyanate in the presence of DMAP affording the corresponding anilide 56 (Scheme 19), which was further subjected to the lithium perchlorate catalysed opening of the noviosyl carbonate portion with $O$-propargylhydroxylamine to provide a mixture of regioisomeric $3^{\prime}$ - and $2^{\prime}$-N-propargyloxycarbamates $\mathbf{5 7}$ and $\mathbf{5 8}$ in the ratio $4: 1$, respectively. The mixture was then used in in vitro experiments without separation. The introduction of an acetyl group in 3-position of sultone 55 by the acetic anhydride was accompanied by the acetylation of 2'-OH of noviose. The hydrolysis of the $2^{\prime}$-acetate fragment with $\mathrm{KOMe}$ in $\mathrm{MeOH}$ gave 1,2-benzooxathiin 2,2-dioxide 59.

Antibacterial properties were studied for the target derivatives $\mathbf{5 7 / 5 8}$ and $\mathbf{5 9}$. According to in vitro studies, compound $\mathbf{5 9}$ had twice the ability to inhibit DNA gyrase compared to a similar compound containing the $\mathrm{C}=0$ group instead of the $\mathrm{SO}_{2}$ fragment, and mixture 57/58 had the same in vitro inhibitory potency towards DNA gyrase as the aminocoumarin antibiotic novobiocin produced by the actinomycete Streptomyces niveus. However, the sultone derivatives were completely devoid of the antibacterial activity as their high polarity had a negative effect on the molecule ability to penetrate cell lipophilic membranes and thus on its antibacterial activity [32].

Taking into account the structural similarity of 1,2-benzoxathiin-4(3H)-one 2,2-dioxide and 4-hydroxycoumarin cores the authors of the work [23] aimed

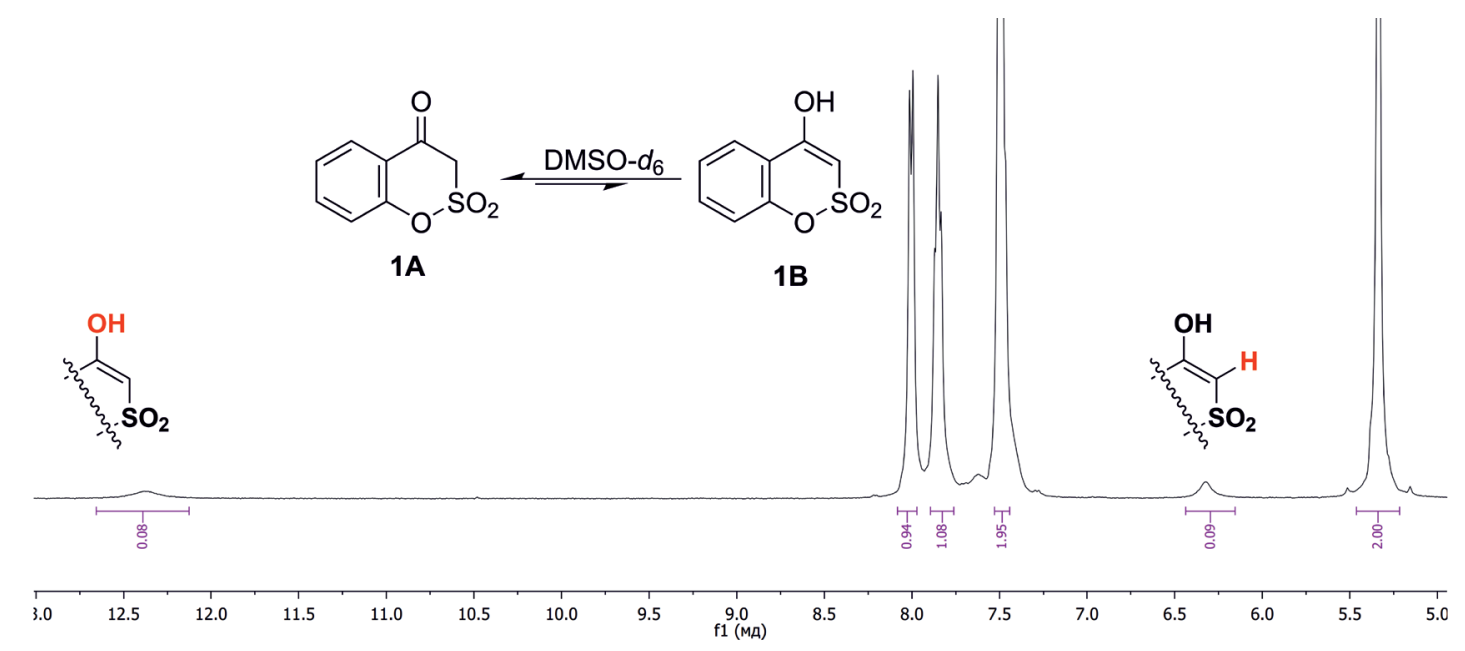

Fig. 3. The ${ }^{1} \mathrm{H}$ NMR spectrum of 1,2-benzoxathiin-4(3H)-one 2,2-dioxide (1) (DMSO- $d_{6}, 400 \mathrm{MHz}$ ), $\delta$, ppm 


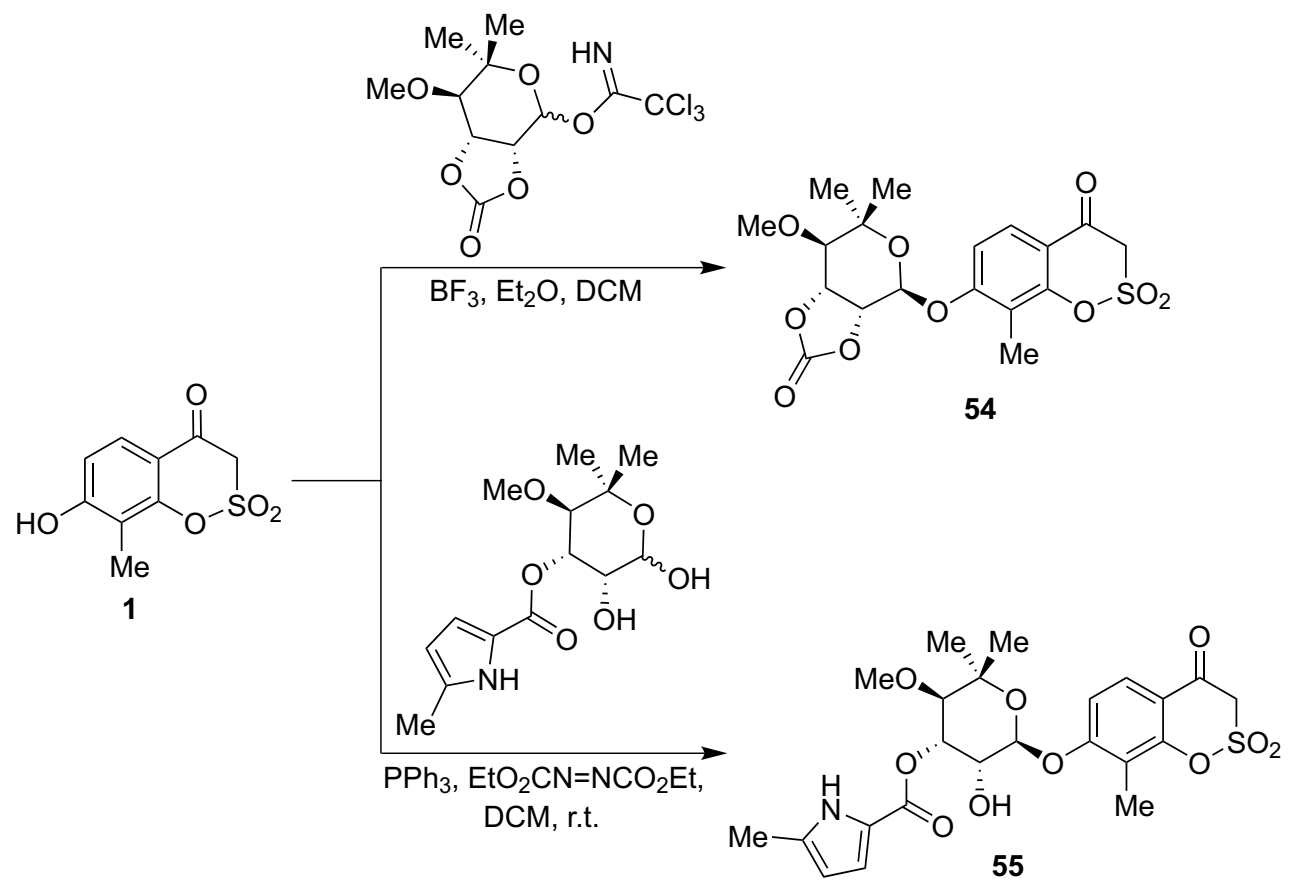

Scheme 18. The synthesis of noviose-comprising derivatives of sultone 1

at the synthesis of coumarin anticoagulant analogs. This was achieved by the Michael addition of the substituted benzalacetones $\mathbf{6 0}$ to sultone $\mathbf{1}$ (Scheme 20). The structure of the products isolated strongly depended on the substituents in the benzene portion of benzalacetones. In this regard, they can exist in acyclic form 61 or hemiketal form $\mathbf{6 3}$, which is apparently formed through enol form $\mathbf{6 2}$. The authors discussed the stereoselectivity of the Michael addition as well. Analyzing ${ }^{1} \mathrm{H}$ NMR spectra they observed

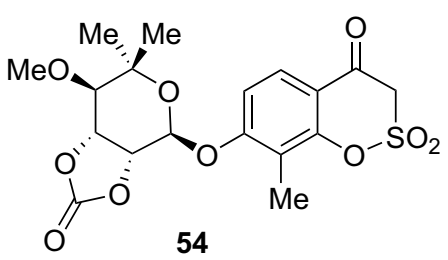

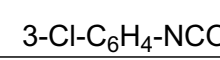
DMAP, DCM, rt.<smiles>COC1C(Oc2ccc3c(O)c(C(=O)Nc4cccc(Cl)c4)c(=O)oc3c2N)OC([N+](=O)[O-])C1OC(=O)O</smiles><smiles>[R]OC1C(Oc2ccc3c(O)c(C(=O)Nc4cccc(Cl)c4)c(=O)oc3c2N)OC(C)(C)C(O[R])C1[R]</smiles><smiles>C#CCON[C@H](Cl)[C@H](C)OC(=O)[OH2+]</smiles><smiles></smiles>

58: $\mathrm{R}^{1}=\mathrm{H}$<smiles>[R]C=CC(=O)NOCC#C</smiles><smiles>COC1C(OC(=O)c2ccc(C)[nH]2)C(O)C(Oc2ccc3c(c2[N+](=O)[O-])O[Sb](=O)(O)CC3=O)OC1(C)C</smiles>

55
1. $\mathrm{Ac}_{2} \mathrm{O}$, DMAP, DCM, r.t.

2. $\mathrm{KOMe}, \mathrm{MeOH}, 0^{\circ} \mathrm{C}$<smiles></smiles>

59

Scheme 19. The synthesis of promising antibacterial agents comprising 1,2-benzoxathiin-4(3H)-one 2,2-dioxide core 

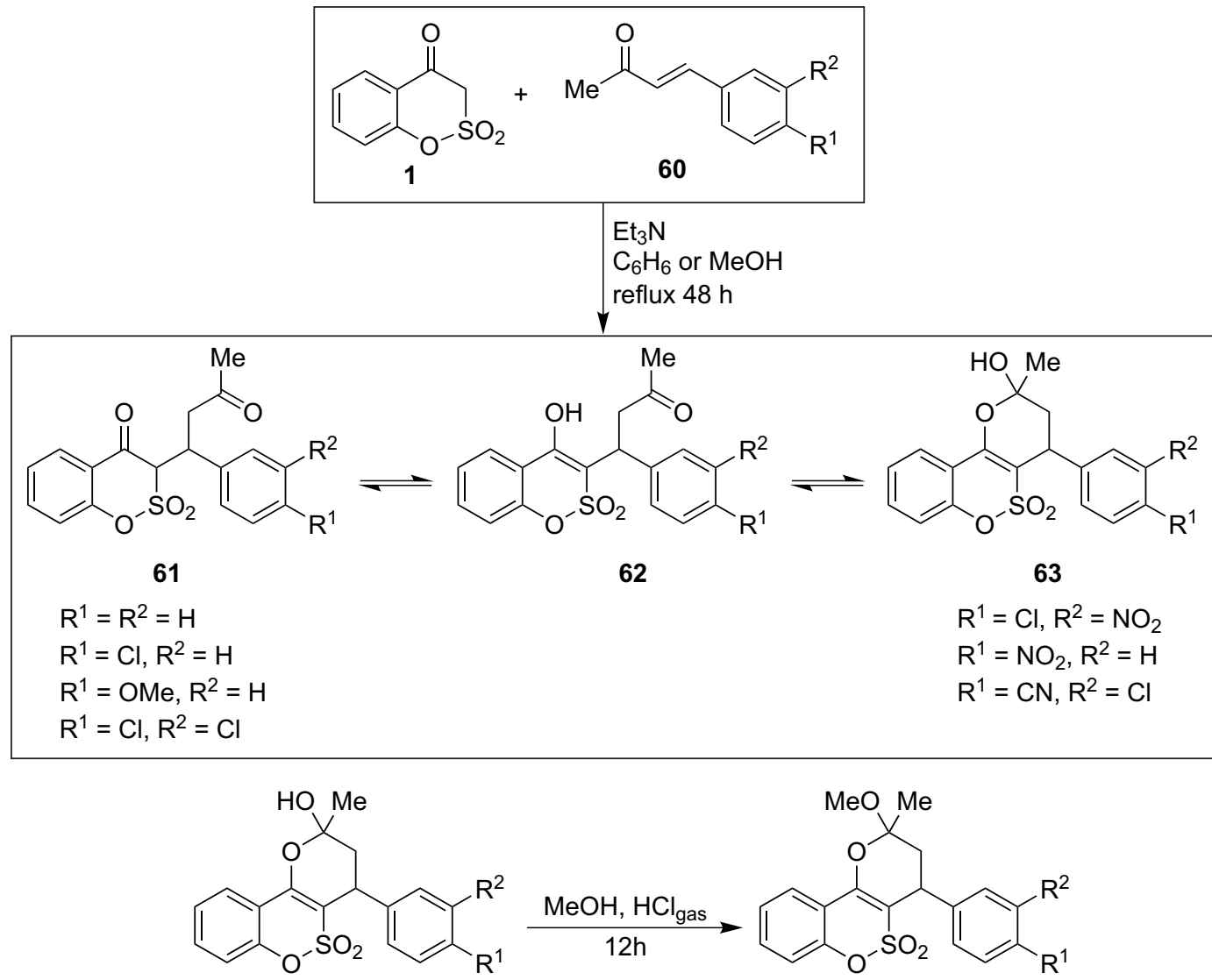

63

64

Scheme 20. The synthesis of coumarin anticoagulant analogs

two sets of signals and made a conclusion about acyclic products that comprised a proton at $\mathrm{C}-3$ in quasiequatorial and quasi-axial positions. Ketals 64 can also be obtained from cyclic Michael adducts $\mathbf{6 3}$ by the ordinary procedure. To study anticoagulant properties, the compounds obtained were orally administered to rats (Table). As a reference drug Warfarin in the dose of $1.25 \mathrm{mg} / \mathrm{kg}$ was taken. Twelve hours after administration of a single dose $(330 \mathrm{mg} / \mathrm{kg})$ of the compounds under research the prothrombin level decreased by average $25 \%$. The maximum level of activity was observed in $24 \mathrm{~h}$. It is worth mentioning that the dose-activity relationship was not linear (when the dose was decreased twice, the level of activity dropped dramatically).

Löwe et al. thoroughly studied chemical properties of 1,2-benzoxathiin-4(3H)-one 2,2-dioxides containing the 3-carbaldehyde moiety or its synthetic analogs.

Using the methylene group reactivity of the starting sultone 1 they synthesized a building block - 4-hydroxy-1,2-benzoxathiine-3-carbaldehyde 2,2-dioxide (29),

Table

The prothrombin time for warfarin and its $\mathrm{SO}_{2}$-analogs after oral administration to rats

\begin{tabular}{|c|c|c|c|c|c|c|c|}
\hline \multirow{2}{*}{$\mathrm{Cmp}$} & \multirow{2}{*}{$\mathrm{R}^{1}$} & \multirow{2}{*}{$\mathrm{R}^{2}$} & \multirow{2}{*}{ Dose, $\mathrm{mg} / \mathrm{kg}$} & \multicolumn{5}{|c|}{ Prothrombin time } \\
\cline { 5 - 8 } & & & & $12 \mathrm{~h}$ & $24 \mathrm{~h}$ & $36 \mathrm{~h}$ & $48 \mathrm{~h}$ \\
\hline $\mathbf{6 1}$ & $\mathrm{H}$ & $\mathrm{H}$ & 350 & $25.6 \pm 2.0$ & $37.9 \pm 3.5$ & $>50$ & $17.3 \pm 1.8$ \\
\hline $\mathbf{6 1}$ & $\mathrm{H}$ & $\mathrm{H}$ & 175 & $15.0 \pm 1.0$ & $14.6 \pm 0.6$ & $13.9 \pm 0.5$ & - \\
\hline $\mathbf{6 1}$ & $\mathrm{Cl}$ & $\mathrm{H}$ & 330 & $44.4 \pm 1.5$ & $>50$ & $15.9 \pm 0.3$ & - \\
\hline $\mathbf{6 1}$ & $\mathrm{OMe}$ & $\mathrm{H}$ & 330 & $24.0 \pm 4.6$ & $20.8 \pm 2.3$ & $16.6 \pm 0.9$ & - \\
\hline $\mathbf{6 1}$ & $\mathrm{Cl}$ & $\mathrm{Cl}$ & 330 & $44.7 \pm 3.9$ & $>50$ & $22.7 \pm 7.3$ & - \\
\hline $\mathbf{6 3}$ & $\mathrm{Cl}$ & $\mathrm{NO}_{2}$ & 330 & $18.9 \pm 0.6$ & $30.4 \pm 9.1$ & $16.4 \pm 0.6$ & - \\
\hline $\mathbf{6 3}$ & $\mathrm{NO}_{2}$ & $\mathrm{H}$ & 330 & $43.8 \pm 3.7$ & $>50$ & $21.8 \pm 10.5$ & - \\
\hline $\mathbf{6 3}$ & $\mathrm{CN}^{\mathbf{6 n n n n y y y y}}$ & $\mathrm{H}$ & 315 & $46.8 \pm 4.2$ & $>50$ & $18.6 \pm 2.1$ & - \\
\hline Warfarin & $\mathrm{NO}_{2}$ & $\mathrm{H}$ & 330 & $32.4 \pm 7.4$ & $19.8 \pm 3.1$ & $18.1 \pm 2.6$ & - \\
\hline
\end{tabular}




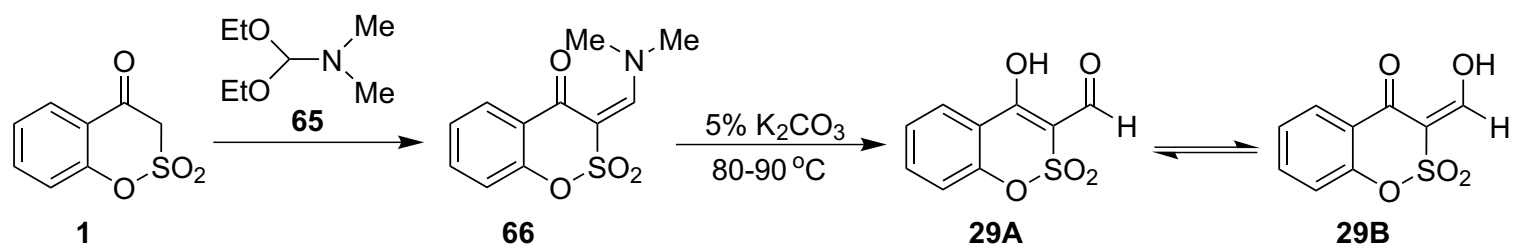

Scheme 21. The synthesis of 4-hydroxy-1,2-benzoxathiine-3-carbaldehyde 2,2-dioxide (29)

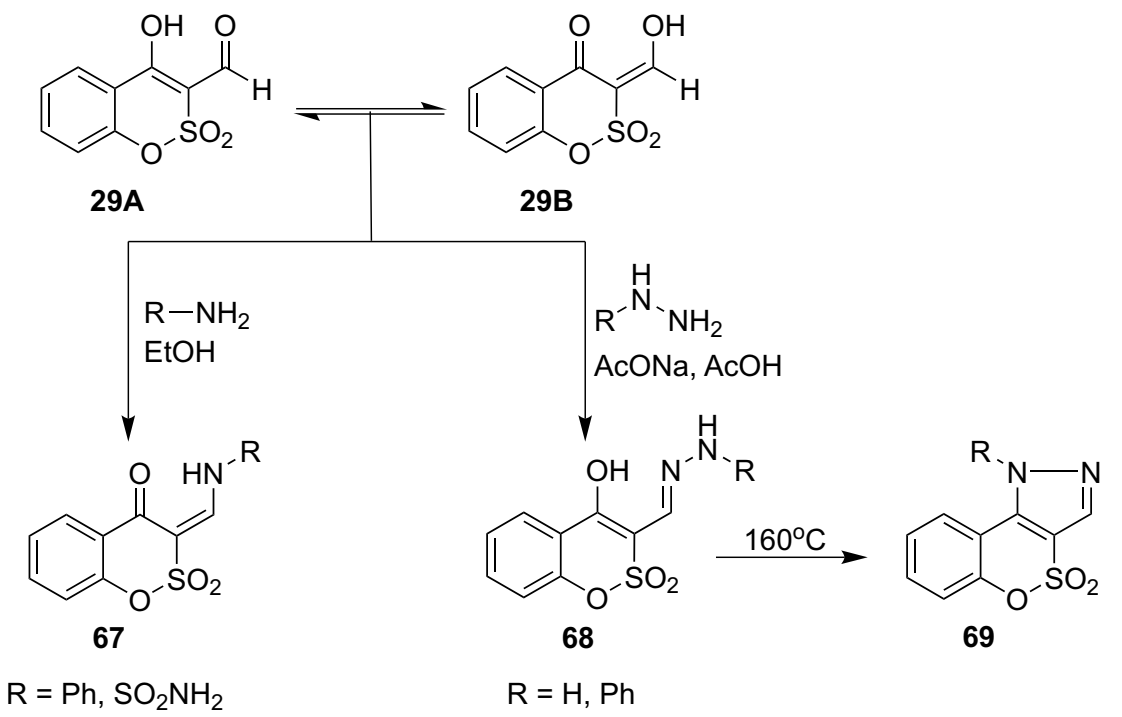

Scheme 22. The interaction of aldehyde 29 with amines and hydrazines

crucial for their research by the interaction of $\mathbf{1}$ with $\mathrm{N}, \mathrm{N}$-dimethylformamide diethyl acetal (65) followed by the alkaline hydrolysis (Scheme 21) [41]. The latter, as mentioned earlier, is characterized by the existence of two tautomeric forms $\mathbf{2 9 A}$ and 29B.

Further, the authors [41] used 4-hydroxy-1,2-benzoxathiine-3-carbaldehyde 2,2-dioxide (29) for the synthesis of enamines $\mathbf{6 7}$ by its interaction with aniline or sulfamide, as well as for the preparation of hydrazones $\mathbf{6 8}$ by its interaction with hydrazine and phenylhydrazine. 1,3-Dielectrophilic nature of the starting aldehyde $\mathbf{2 9}$ allowed hydrazones $\mathbf{6 8}$ to be cyclized to the condensed benzoxathiinopyrazoles 69 upon the subsequent heating (Scheme 22).

Considering the prospects of 4-hydroxy-1,2-benzoxathiine-3-carbaldehyde 2,2-dioxide (29) for the synthesis of condensed heterocyclic systems Löwe et al. used this compound in further studies to obtain 1,2-benzoxathiin [4,3- $d]$ pyrimidine 5,5 -dioxides $\mathbf{7 0}$ (Scheme 23) [42]. To form a pyrimidine ring, [3+3]cyclocondensation was performed with amidine acetates (formamidinium acetate and guanidinium acetate) by fusing the starting compounds without the use of a solvent.

A range of 1,2-benzoxathiin[4,3- $d$ ] pyrimidine 5,5dioxides $\mathbf{7 0}$ was then expanded by an approach involving the ability of chromone-3-sulfonic acid phenyl ester (71) to be recyclized by N-nucleophiles [36]. According to the mechanism proposed by the authors at the first stage there was 1,4-addition of amidine to the chromone ring with the subsequent deprotona- tion, recyclization and formation of a condensed system of the sultone and pyrimidine rings $\mathbf{7 0}$ (Scheme 24).

The ability of chromone-3-sulfonic acid phenyl ester (71) to recyclization transformations was also used by Löwe et al. to obtain a number of 1,2-benzoxathiine 2,2-dioxide derivatives condensed with the pyridine nucleus. Thus, in the work [43] the interaction of compound $\mathbf{7 1}$ with methyl 3-aminocrotonate (72) was studied. The reaction was performed by fusing the starting materials in the presence of sodium acetate. As a result, a mixture of two products was isolated, it was separated by thin layer chromatography, and the compounds were identified as methyl 2-methyl-1,2-benzoxathiin [4,3-b] pyridine-3-carboxylate 5,5-dioxide (73) and methyl 1,2-benzoxathiin[4,3-b]pyridine-2-acetate 5,5-dioxide (74) (Scheme 25).

In order to explain the unusual result of forming two products in this interaction, the authors proposed several mechanisms for its course. The first path involves the Michael reaction, in which the $\mathrm{C}-2$ atom of enaminoester $\mathbf{7 2}$ attacks the $\mathrm{C}-2$ atom of chromone $\mathbf{7 1}$,

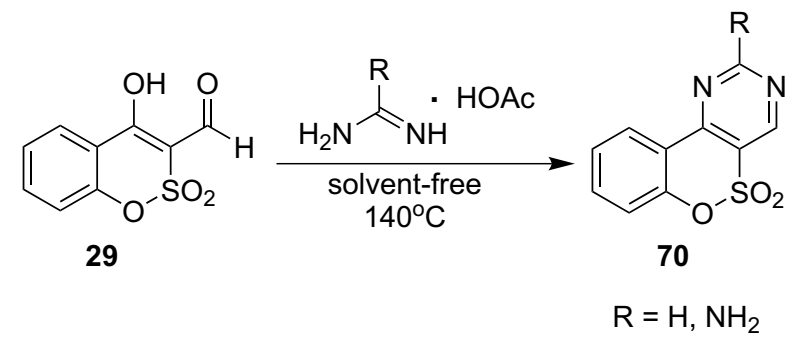

Scheme 23. The synthesis of 1,2-benzoxathiin[4,3-d]pyrimidine 5,5-dioxides 70 


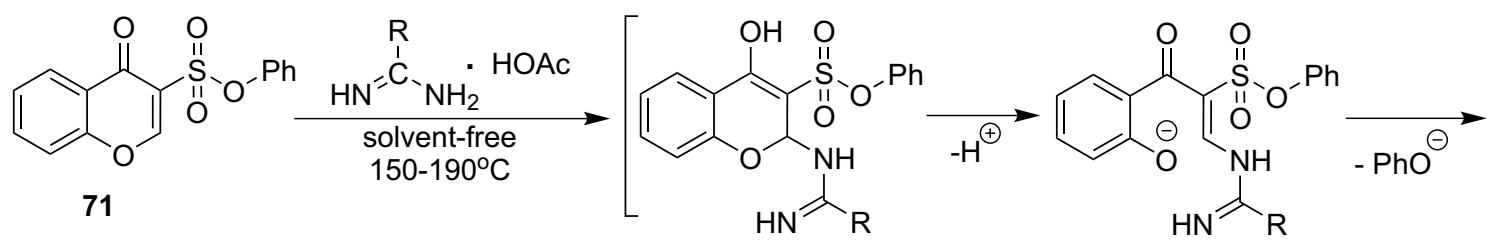<smiles>[R]C(N)=N/C=C1/C(=O)c2ccc(CC)cc2O[R]1(=O)=O</smiles>

$\mathrm{R}=\mathrm{H}, \mathrm{NH}_{2}, \mathrm{Me}, \mathrm{Ph}, \mathrm{SBn}$

Scheme 24. The recyclization of chromone-3-sulfonic acid phenyl ester (71) with $\mathrm{N}$-nucleophiles<smiles>COC(=O)/C=C(/N)C(=O)O[Na]</smiles>

Scheme 25. The interaction of phenyl ester $\mathbf{7 1}$ with methyl 3-aminocrotonate (72)

forming the zwitter-ion $\mathbf{A}$, which is characterized by tautomeric equilibrium (Scheme 26). It is followed by sequential deprotonation (B), dehydration and cleavage of the phenolate anion to form the reaction product 73.

As for compound $\mathbf{7 4}$ isolated as a result of the interaction studied, the authors proposed two possible mechanisms of its formation. According to the first of them the rearrangement occurs in an already closed pyridine cycle (Scheme 27).

The second probable mechanism involves the nucleophilic attack of $\mathrm{C}-2$ atom of chromone $\mathbf{7 1}$ by the C-4 atom of enaminoester $\mathbf{7 2}$ as a result of tautomeric transformations of the latter (Scheme 28).

As a result of the abovementioned reaction (Scheme 25), according to the authors, one could expect<smiles></smiles>

71

72

A

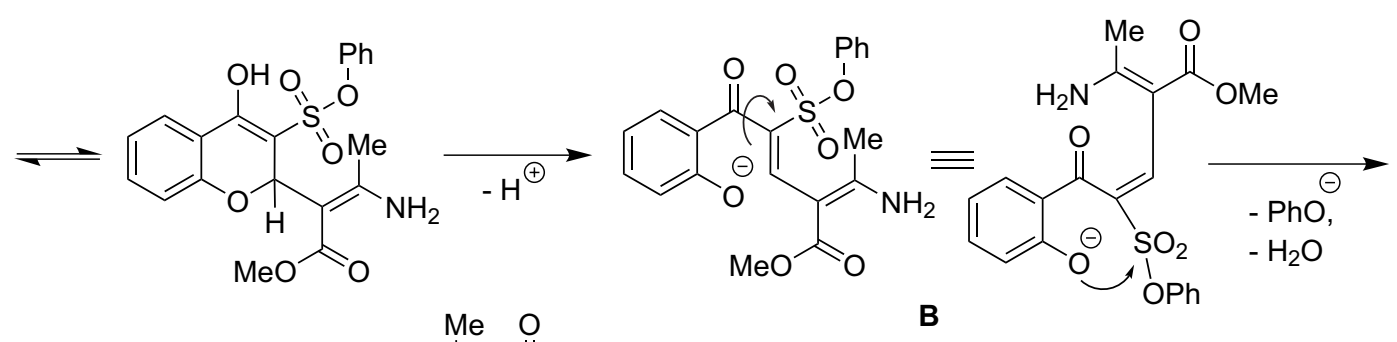<smiles>COC(=O)c1cc2c(nc1C)-c1ccccc1OS2(=O)=O</smiles>

73

Scheme 26. The mechanism of the interaction of phenyl ester $\mathbf{7 1}$ with methyl 3-aminocrotonate (72) 
<smiles>COC(=O)C(C=C(C(=O)O)C(=O)Oc1ccccc1)=C(N)N</smiles><smiles>COC(=O)c1cc(S(=O)(=O)Oc2ccccc2)c(-c2ccccc2[O-])nc1C</smiles><smiles></smiles>

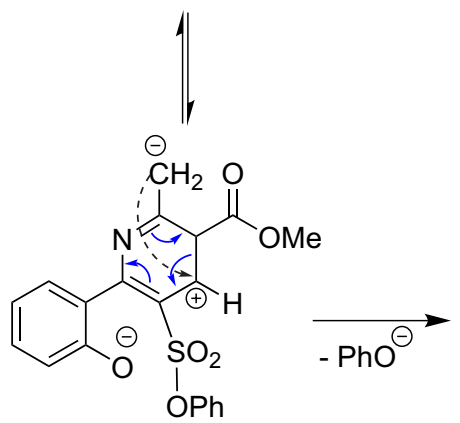<smiles>[Z4]OS(=O)(=O)c1ccc(CC(=O)OC)nc1-c1ccccc1</smiles>

Scheme 27. The mechanism of the interaction of phenyl ester $\mathbf{7 1}$ with methyl 3-aminocrotonate (72)

the formation of another product - the structural isomer of the compounds obtained - derivative 75 . This process is possible under the condition of the nucleophilic attack of the amino group of ester $\mathbf{7 2}$ on the chromone ring. However, compound $\mathbf{7 5}$ was neither isolated nor identified (Fig. 4).

In the work [44] the authors used enaminoester 76 having one carbon atom more than aminocrotonate $\mathbf{7 2}$ in the reaction with chromone $\mathbf{7 1}$. As the result, they isolated a mixture of three compounds containing another possible product of similar interactions - derivative 79. The mixture was managed to be separated by chromatography on silica gel (Scheme 29).

The authors proposed the mechanism for this interaction. For compounds $\mathbf{7 7}$ and $\mathbf{7 8}$ it was consistent with the studies presented in [44] (Schemes 26-28).
The formation of compound $\mathbf{7 9}$, which does not contain a nitrogen atom in the ring, is explained by the primary interaction of the amino group of enaminoester 76 with the $\mathrm{C}-2$ atom of phenyl chromone-3-sulfonate (71) (Scheme 30). In this case, the reaction intermediate $\mathbf{A}$ is deprotonated with the opening of the cycle, the substitution of the phenolate anion and the formation of the sultone ring (B). Intermediate $\mathbf{B}$ undergoes the hydrolytic cleavage, and the compounds obtained then interact with each other to form an unstable intermediate $\mathbf{C}$. The $\mathbf{O}-\mathrm{S}$ bond breaking within $\mathbf{C}$ leads to disclosure of the sultone cycle and formation of zwitter-ion $\mathbf{D}$ from which a cyclic aldehyde $\mathbf{E}$ is produced by the lactone ring closure. Finally, the hydrolysis of the latter leads to the formation of the final product - 4-ethyl-5H-[1,2]oxathiino[5,4-c]chromen-5-one 2,2-dioxide (79).

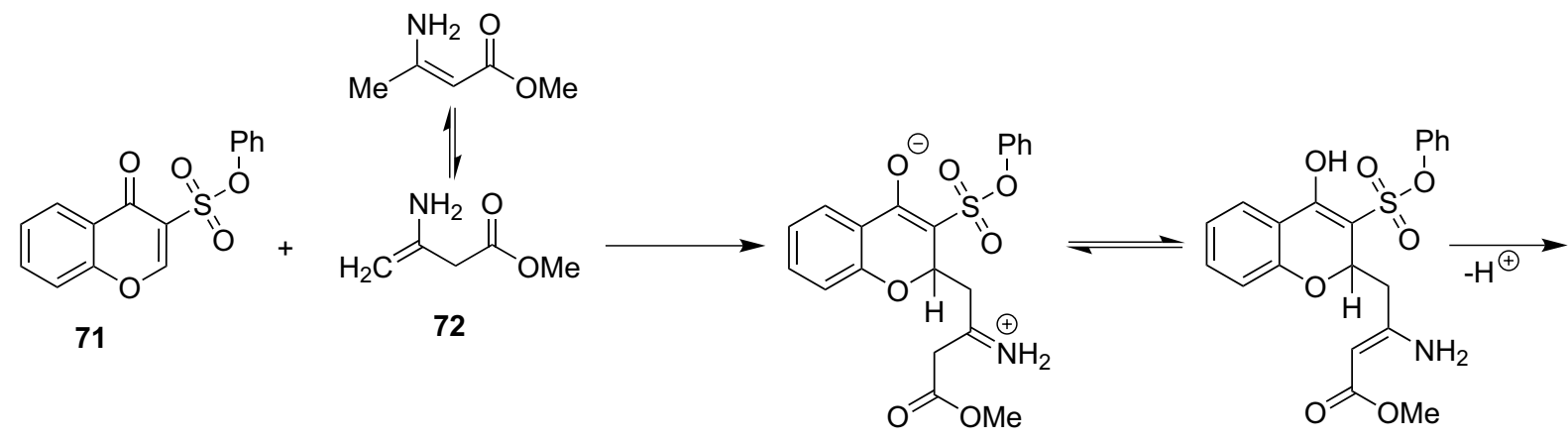

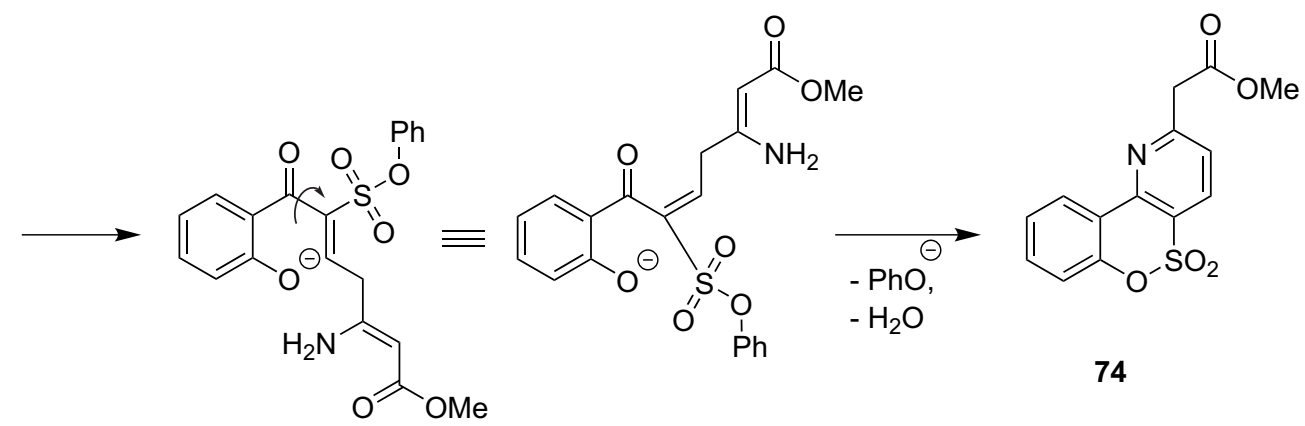


<smiles>CC(=O)c1c(C)ncc2c1-c1ccccc1OS(=O)(=O)O2</smiles>

Fig. 4. Not isolated possible product of the interaction of phenyl ester $\mathbf{7 1}$ with methyl 3-aminocrotonate (72)

The mechanism proposed has been proven by the fact that enaminone $\mathbf{2 8}$ obtained in another way [36] when interacting with methyl 3-oxopentanoate also forms product 79. At the same time, one cannot exclude that enaminone $\mathbf{2 8}$ is the product of the interaction of the starting compound $\mathbf{7 1}$ with ammonia formed by the in situ hydrolysis of methyl 3-amino-2-pentenoate (76).

Continuing the study of enaminone $\mathbf{2 8}$ Löwe et al. studied the interaction of this compound with $\beta$-ketoesters $\mathbf{8 0 - 8 2}$ in the presence of sodium acetate under fusion [45] (Scheme 31). It was found that the outcome of such interactions strongly depended on the $\beta$-ketoester used. Thus, application of $\mathbf{8 0}$ led to 1,4-addition intermediate $\mathbf{A}$ which cyclized giving dibenzo annulated sultone $\mathbf{8 3}$. The use of $\beta$-ketoester $\mathbf{8 1}$ led to the loss of selectivity. As a result of this interaction, the formation of three reaction products 84-86 was observed; they were separated by thin layer chromatography. For esters $\mathbf{8 2}$, the reaction proceeded as 1,2 addition with the formation of condensed derivatives 87 solely. Compounds 84, 86, 87 were formed in accordance with mechanisms discussed before, pentasubstituted benzene $\mathbf{8 5}$ was the product of compound $\mathbf{8 1}$ self-condensation.

In many previous studies chromone and its derivatives were used to synthesize the benzoxathiine nucleus. Therefore, it should be noted that only one work describes the inverse conversion of benzoxathiine nucleus to the chromone one [46]. It was achieved by the interaction of 3-formyl-4-hydroxy-1,2-benzoxathiine

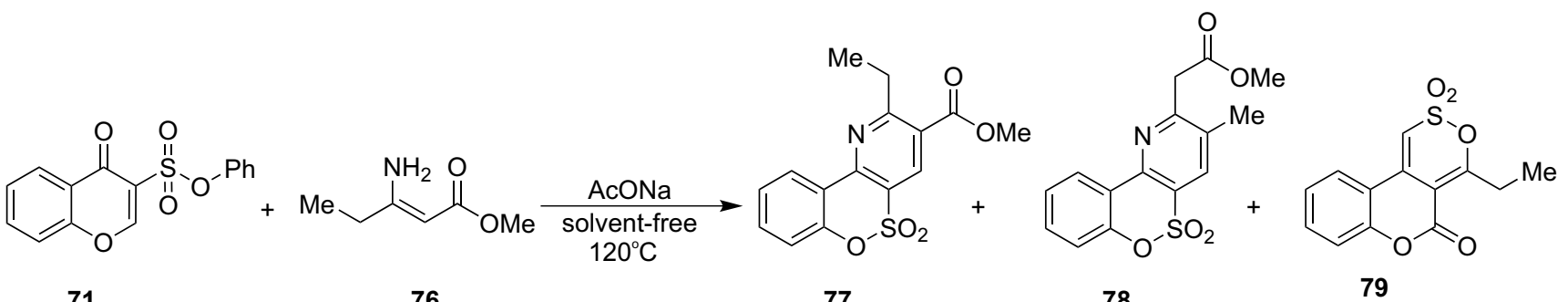

71

76

77

Scheme 29. The interaction of phenyl ester 71 with methyl 3-aminopent-2-enoate (76)<smiles>O=c1c(S(=O)(=O)O[InH])coc2ccccc12</smiles>

71<smiles>CC/C(N)=C/C(=O)OC</smiles>

76<smiles>CC/C(=C/C(=O)OC)NC1Oc2ccccc2C(O)=C1S(=O)(=O)Oc1ccccc1</smiles>

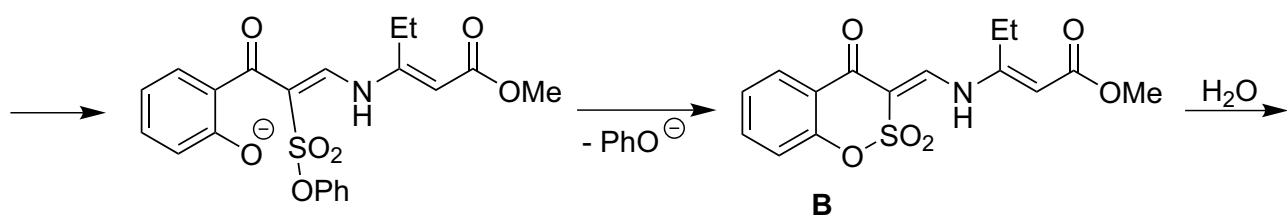

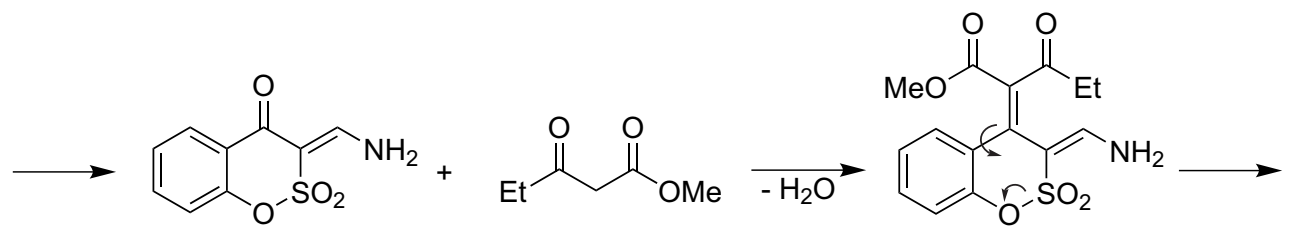

28

C

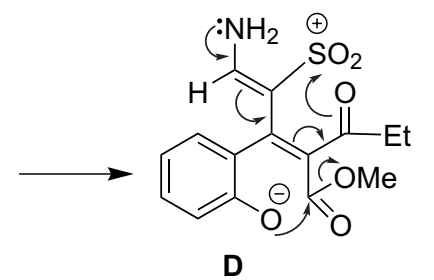

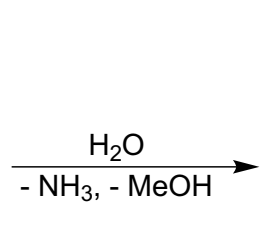
$-\mathrm{NH}_{3},-\mathrm{MeOH}$

Scheme 30. The mechanism of compound 79 formation<smiles>[M]CC1=c2c(c(=O)oc3ccccc23)=C(C=O)[Se]O1</smiles>

E<smiles>CCC1=c2c(=O)oc3ccccc3c2=C[R5](=O)O1</smiles>

79 


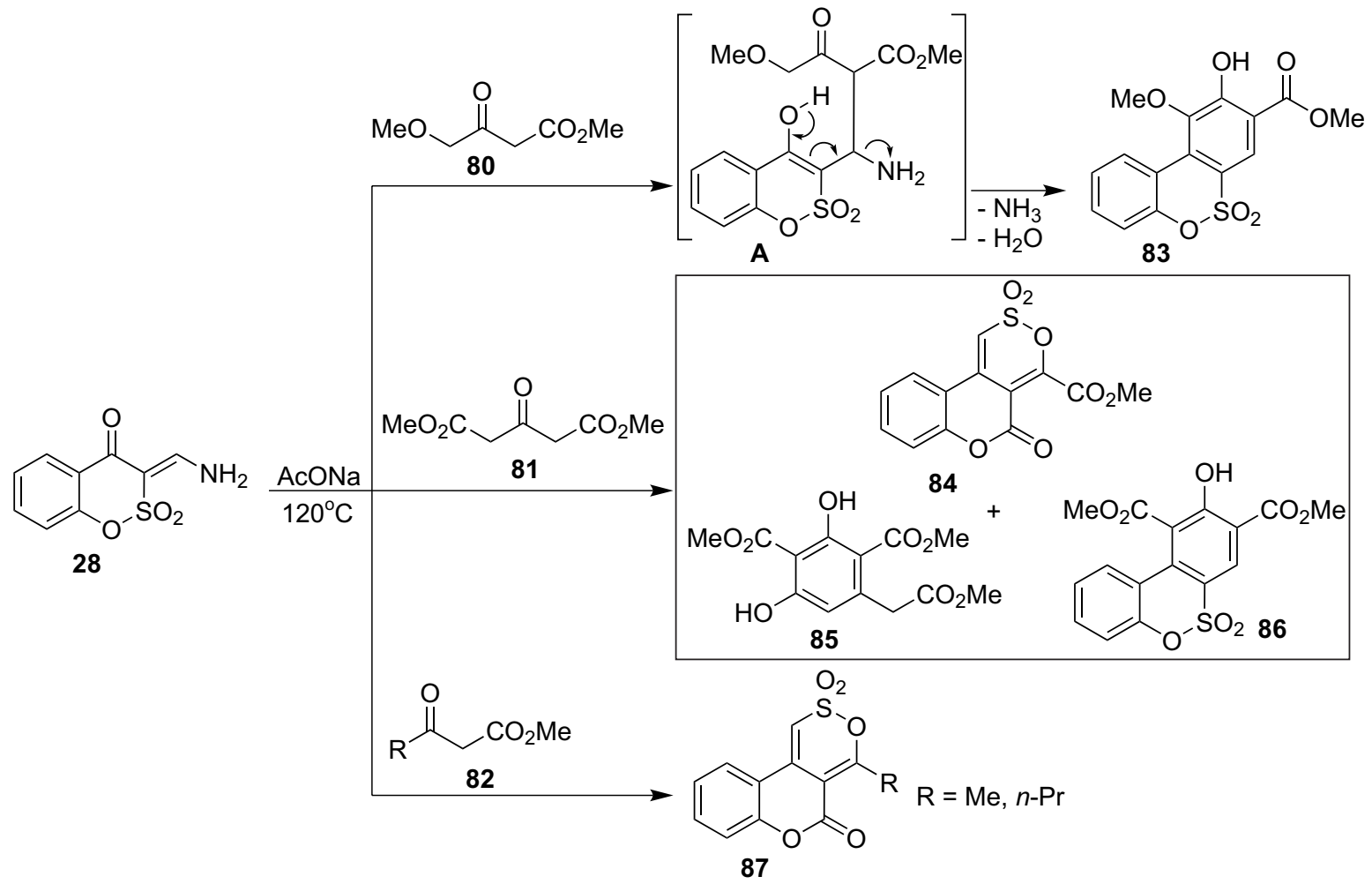

Scheme 31. The interaction of enaminone 28 with $\beta$-ketoesters

2,2-dioxide (29) with hydroxylamine hydrochloride in pyridine and acetic anhydride and resulted in 2-aminochromon-3-sulfonic acid (88) (Scheme 32). A stepwise format of the conversion with the preliminary synthesis of oxime $\mathbf{8 9}$ and the subsequent rearrangement under the action of sodium ethoxide is also possible. The authors believe that the conversion proceeds with the formation of acyclic intermediate A. Analyzing ${ }^{1} \mathrm{H}$ NMR spectra the authors make a conclusion that chromone $\mathbf{8 8}$ is a tautomeric compound and exists in 2 tautomeric forms - a predominating amino-form 88A and a minor imino-form 88B.

Another synthetic application of aldehyde 29 is the preparation of nitrile $\mathbf{9 1}$. It is a two-stage process which requires isolation of the corresponding pyridinium salt 90 (Scheme 32).

The previous transformations (Scheme 32) and some reactions mentioned before reveal a labile nature

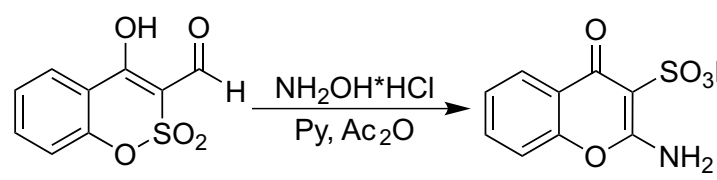

29

$\mathrm{NH}_{2} \mathrm{OSO}_{3} \mathrm{H}$

$\mathrm{EtOH}$<smiles>O=S1(=O)Oc2ccccc2C1=CO</smiles>

89

$\mathrm{Py}, \mathrm{Ac}_{2} \mathrm{O}$

reflux, $2 \mathrm{~h}$<smiles>N#Cc1c(O)c2ccccc2oc1=O</smiles>

90<smiles>N#Cc1c(O)c2ccc(NC(=O)O)cc2oc1=O</smiles>

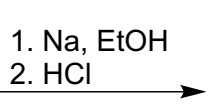
88A<smiles></smiles><smiles>C=C</smiles><smiles>O=C(c1ccccc1O)C(C=NO)[SH](=O)=O</smiles>

A<smiles>N=C1Oc2ccccc2C(=O)C1[Se]O</smiles>

88B 
<smiles>CC1C(=O)c2cc(Cl)cc(Cl)c2OS1(=O)=O</smiles>

92<smiles></smiles>

93

Scheme 33. The ring-opening reaction of sultone 92 with pyrrolidine

of the $\mathrm{O}-\mathrm{SO}_{2}$ bond, which can break under basic conditions. This property was used by R. Meyer [21] to obtain acyclic sulfonamide 93 by refluxing sultone 92 in excess of pyrrolidine (Scheme 33).

The presence of the $\mathrm{SO}_{2} \mathrm{CH}_{2} \mathrm{CO}$ fragment in the molecule of 1,2-benzoxathiin-4(3H)-one 2,2-dioxide (1) provides opportunities for the synthesis of the condensed heterocyclic systems based on it, but by now this synthetic direction is underinvestigated. The authors [41] used the interaction of the starting sultone 1 with 2aminobenzaldehyde in acetic acid. As a result, a new condensed tetracyclic system - 3,4-dihydro-1,2-benzoxathiin [4,3-b]quinoline-6,6-dioxide (94) was obtained (Scheme 34).

Another work [29] used the $\mathrm{SO}_{2} \mathrm{CH}_{2} \mathrm{CO}$ fragment for the synthesis of new heterosteroidic systems. A key intermediate for this purpose - 4-oxo-3,4-dihydro-2 $H$-thiopyrano[3,2-c][1,2] benzooxathiin 5,5dioxide (95) was obtained by the annelation of the thiopyrane nucleus to 1 either by a direct interaction of the latter with $\beta$-mercaptopropionic acid or by the stepby-step approach with the preliminary synthesis of 98 (Scheme 35). It is worth noting that these reactions were not selective and gave rise to a mixture of products, which authors managed to separate.

The newly formed $\mathrm{CH}_{2} \mathrm{CO}$ fragment in $\mathbf{9 5}$ gave great opportunities to the authors to build various heterocyclic moieties - pyrazole, isoxazole, pyrrole, thiazole (Scheme 36).

A set of works [47-53] were aimed at studying the multicomponent interaction of 1,2-benzoxathiin4(3H)-one 2,2-dioxide (1), active methylene nitriles and carbonyl compounds in order to synthesize a new

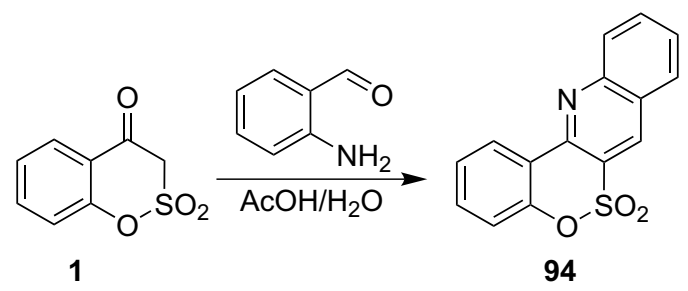

Scheme 34. The interaction of sultone 1 with 2-aminobenzaldehyde

condensed heterocyclic system of 2 -amino-3- $\mathrm{R}^{1}-4-\mathrm{R}^{2}$ 4,6-dihydropyrano[3,2-c][2,1] benzoxathiine 5,5-dioxide (Fig. 5). These studies were the first and by now are the only investigations dedicated to the application of 1,2-benzoxathiin-4(3H)-one 2,2-dioxide (1) in multicomponent processes. Considering the target dihydropyrano[3,2-c] $[2,1]$ benzoxathiine 5,5 -dioxides as those containing 2 promising pharmacophore units the authors also focused on determining the biological activity of the compounds synthesized.

The authors [47, 50-53] determined that the interaction of 1,2-benzoxathiin-4(3H)-one 2,2-dioxide (1) with aldehydes $\mathbf{1 1 0}$ and malononitrile (111) gave a number of 2-amino-4-R-4H-pyrano[3,2-c][1,2] benzoxathiine-3-carbonitrile 5,5-dioxides 112 in moderate to high yields (Scheme 37). The interaction required a base as a catalyst, which was triethylamine in most cases. It was also found that in cases of aliphatic and alicyclic aldehydes heating was redundant and might lead to fail in isolation or significant decrease in yields of the final products. The two-step approach towards the target 2-amino- $4 H$-pyran-3-carbonitriles $\mathbf{1 1 2}$ with the use of $\alpha$-cyanoacrylonitriles 113 is also possible as shown on examples of heteroaromatic aldehydes 99. However, this stepwise format has no advantages comparing to the one-pot process as it leads to lower yields and requires more time to be completed.

It should be also mentioned that a successful outcome of the reaction of the synthesis of 2-amino- $4 \mathrm{H}$ pyran-3-carbonitriles $\mathbf{1 1 2}$ is limited by an aldehyde used. Thus, compounds $\mathbf{1 1 2}$ were not managed to be obtained in cases of electron-rich (hetero)aromatic

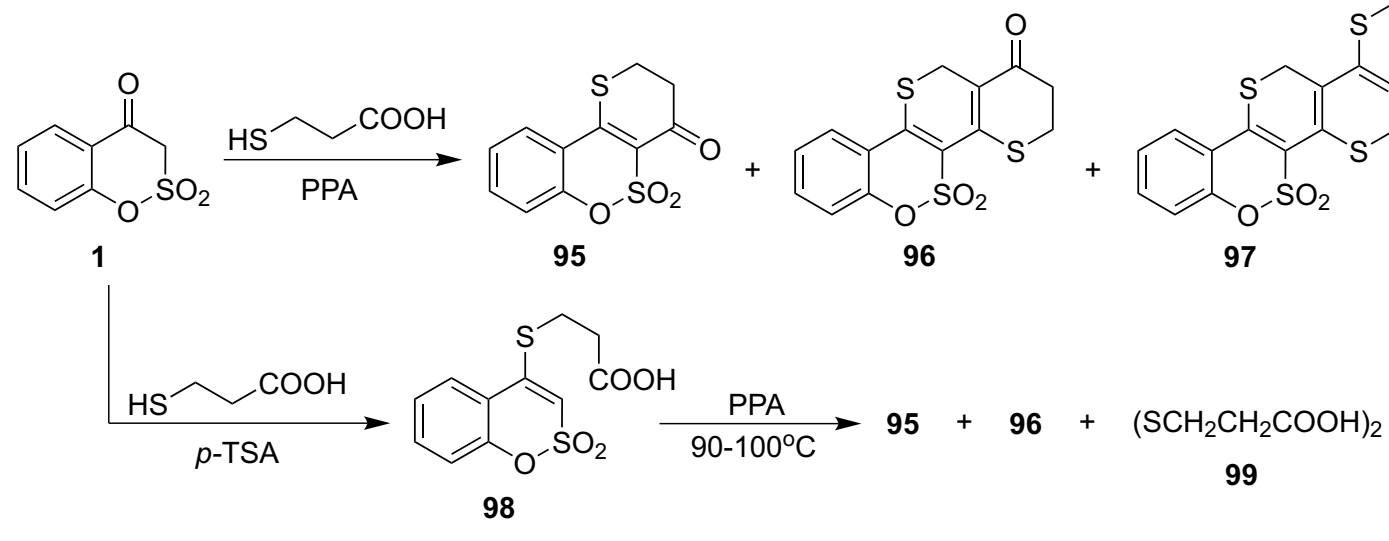

Scheme 35. The use of the $\mathrm{SO}_{2} \mathrm{CH}_{2} \mathrm{CO}$ fragment in sultone 1 for the synthesis of sulfur-containing condensed systems 


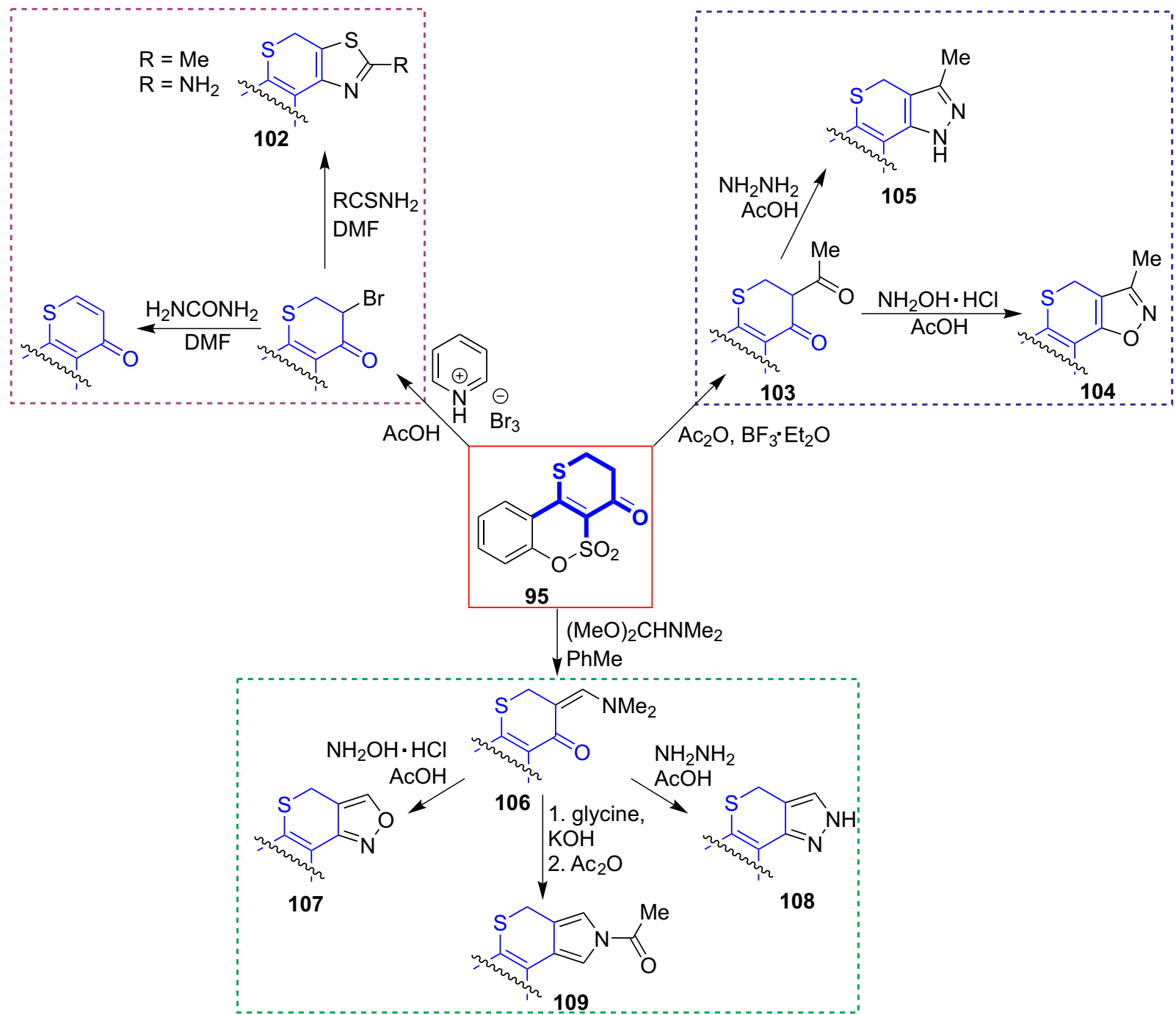

Scheme 36. The modification ways of compound 95

aldehydes (4-dimethylaminobenzaldehyde, $\mathrm{N}$-methylpyrrol-2- and indol-3-carbaldehydes) or benzaldehydes with bulky substituents (9-anthracencarbaldehyde). The only products isolated were $\alpha$-cyanoacrylonitriles 113.

Taking into account the ease of forming 2-amino-4H-pyran-3-carbonitriles $\mathbf{1 1 2}$ in further studies the authors applied ethyl cyanoacetate (114) instead of malononitrile in order to expand a number of the target condensed 2-amino-4-aryl-4H-pyrans (Scheme 38) [47]. However, in this case the loss of the reaction selectivity was observed. The analysis of the reaction mixture by the ${ }^{1} \mathrm{H}$ NMR method evidenced the simultaneous formation of the target ethyl 2-amino-4-aryl-

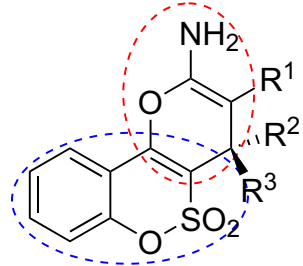

Fig. 5. 2-Amino-3- $R^{1}-4-R^{2}-4,6$-dihydropyrano[3,2-c] $[2,1]-$ benzoxathiine 5,5-dioxides - compounds containing 2 promising pharmacophore units
4H-pyran-3-carboxylates $\mathbf{1 1 5}$, triethylammonium salts 116 and ethyl $\alpha$-cyano- $\beta$-arylacrylates 117 (Scheme 38). These triethylammonium salts were isolated for the first time in the study on similar interactions involving N-ethyl-1H-2,1-benzothiazin-4(3H)one 2,2-dioxide (nitrogen-containing analogue of compound 1) [54, 55]. Thus, it can be assumed that this chemical behavior is a common property of cyclic $\mathrm{SO}_{2}$-containing enolnucleophiles having a fragment of $\mathrm{XSO}_{2} \mathrm{CH}_{2} \mathrm{CO}$.

A number of approaches was used by the authors in order to synthesize the target compounds $\mathbf{1 1 5}$ selectively, namely the use of the ethyl cyanoacetate excess (its effectiveness was revealed earlier [55]), different heating modes, the variation of catalysts, as well as the two-component approach [47]. All of them were not successful, but the experiments carried out allowed researchers to propose a possible mechanism of the three-component interaction (Scheme 39).

According to it Michael adduct $\mathbf{A}$, which is a recognized intermediate in these interactions, can be further transformed by two ways (Scheme 39). The first way is the desired heterocyclization (hetero-Thorpe- 


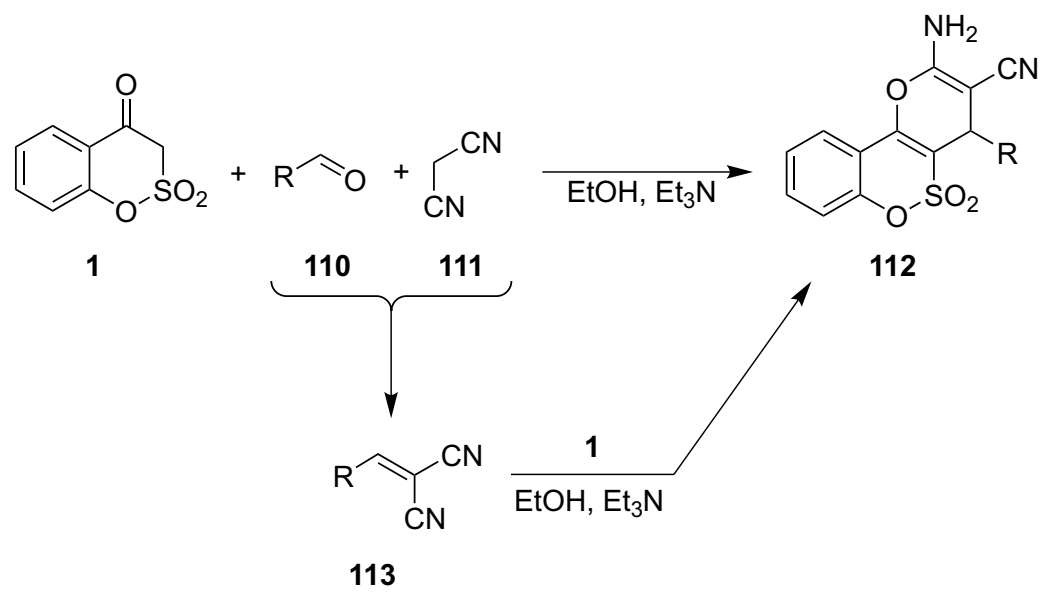

$\mathbf{R}=\mathrm{H}, \mathrm{Ph}, 2-\mathrm{MeO}-\mathrm{C}_{6} \mathrm{H}_{4}, 4-\mathrm{MeO}-\mathrm{C}_{6} \mathrm{H}_{4}, 4-\mathrm{HO}-3-\mathrm{MeO}-\mathrm{C}_{6} \mathrm{H}_{3}$, 3,4,5-triMeO- $\mathrm{C}_{6} \mathrm{H}_{2}, 2-\mathrm{EtO}_{2} \mathrm{CCH}_{2} \mathrm{O}-\mathrm{C}_{6} \mathrm{H}_{4}, 2-\mathrm{NCCH}_{2} \mathrm{O}-\mathrm{C}_{6} \mathrm{H}_{4}$, 4- $\mathrm{Cl}-\mathrm{C}_{6} \mathrm{H}_{4}, 4-\mathrm{NO}_{2}-\mathrm{C}_{6} \mathrm{H}_{4}, 3-\mathrm{Cl}-\mathrm{C}_{6} \mathrm{H}_{4}, 4-\mathrm{F}-\mathrm{C}_{6} \mathrm{H}_{4}, 3-\mathrm{F}-\mathrm{C}_{6} \mathrm{H}_{4}$, 4- $\mathrm{HO}-\mathrm{C}_{6} \mathrm{H}_{4}, 3-\mathrm{HO}-\mathrm{C}_{6} \mathrm{H}_{4}, 4-\mathrm{CF}_{3}-\mathrm{C}_{6} \mathrm{H}_{4}, 4-\mathrm{CH}_{3} \mathrm{~S}-\mathrm{C}_{6} \mathrm{H}_{4}, 4-\mathrm{NC}-\mathrm{C}_{6} \mathrm{H}_{4}$, 4- $\mathrm{HO}_{2} \mathrm{C}-\mathrm{C}_{6} \mathrm{H}_{4}$, pyridin-3-yl, pyridin-4-yl, thienyl-2, furyl-2, 1-phenyl-3-methyl-5-chloropyrazol-4-yl, 1-phenyl-3-ethoxycarbonylpyrazol-4-yl cyclopropyl, cyclopentyl, cyclohexyl, Me, Et, n-Pr, n-Bu, i-Pr, i-Bu, 1-phenylprop-1-en-2-yl

Scheme 37. The three-component interaction of 1,2-benzoxathiin-4(3H)-one 2,2-dioxide (1) with aromatic aldehydes 110 and malononitrile (111)

Ziegler reaction) and the enamine-imine tautomerism to form product 115. The second one is the retro-Michael reaction with the elimination of ethyl cyanoacetate $(\mathbf{1 1 4})$ and the formation of enone $\mathbf{B}$, which reacts with the second molecule of benzothiinone $\mathbf{1}$ forming ammonium salts 116. Apparently, the transformation of salt 116 into ethyl 2-amino- $4 H$-pyran-3-carboxylates $\mathbf{1 1 5}$ is also possible by means of the reverse reactions.

The mechanism proposed is supported by a set of experiments performed in the work [47], in which the authors study the possibility of interconversions between derivatives 115, 116 and 112 (Scheme 40). The mutual transformations of derivatives $\mathbf{1 1 5}$ and 116 prove reversibility of the key stages of the reaction mechanism (Scheme 39). Moreover, the results obtained allowed explaining the facts that the 2-amino4H-pyran-3-carbonitriles $\mathbf{1 1 2}$ were formed as single products in the three-component interaction, whereas the application of ethyl cyanoacetate $(\mathbf{1 1 4})$ resulted in the isolation of the products mixture.

Based on the data obtained it was assumed that the formation of relatively unstable salts $\mathbf{1 1 6}$ during the reaction (Scheme 39) might shift the equilibrium towards the formation of the target 2-amino- $4 \mathrm{H}$-pyrans 115. To test this hypothesis, sodium acetate was used as a basic catalyst in the two-component interaction, assuming that the corresponding sodium salt 116 formed under the reaction conditions would be less stable as compared to the triethylammonium salts. The use of this catalyst allowed to isolate pure ethyl 2-amino-4-phenyl-4H-pyran-3-carboxylate 115a (Scheme 41). A rather unexpected result was occasionally obtained during the measurement of the ${ }^{1} \mathrm{H}$ NMR spectra of 115a. This fact refers to the stability of ethyl 2-amino- $4 H$-pyran-3-carboxylate 115a obtained. ${ }^{1} \mathrm{H}$ NMR spectra of $115 a$ recorded $24 \mathrm{~h}$ and $48 \mathrm{~h}$ after its dissolution in DMSO- $d_{6}$ showed the presence

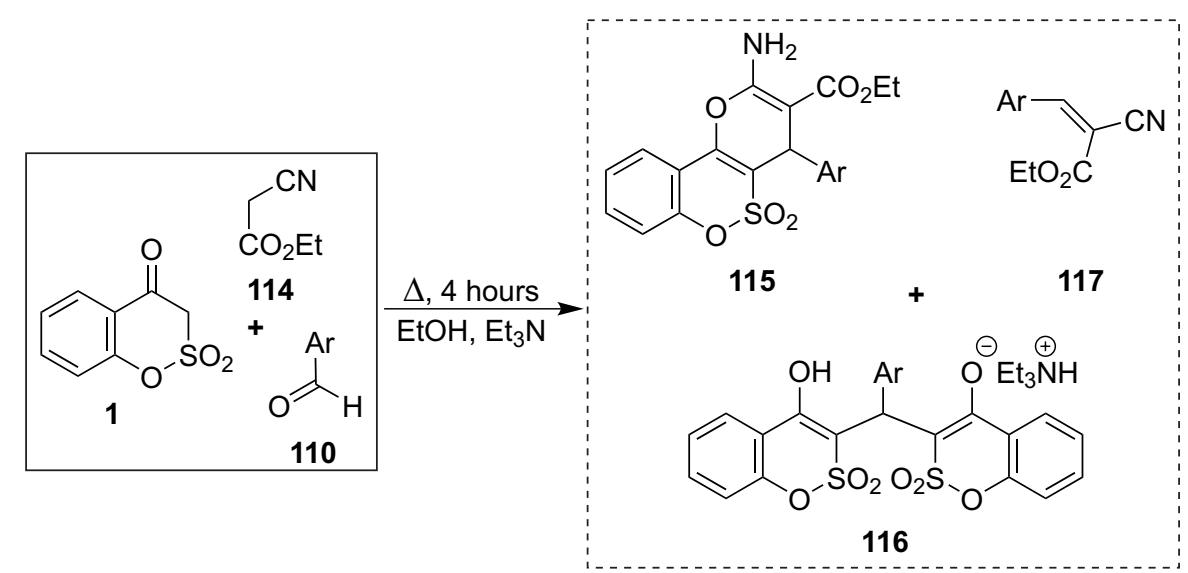

Scheme 38. The three-component interaction of 1,2-benzoxathiin-4(3H)-one 2,2-dioxide (1) with aromatic aldehydes 110 and ethyl cyanoacetate (114) 


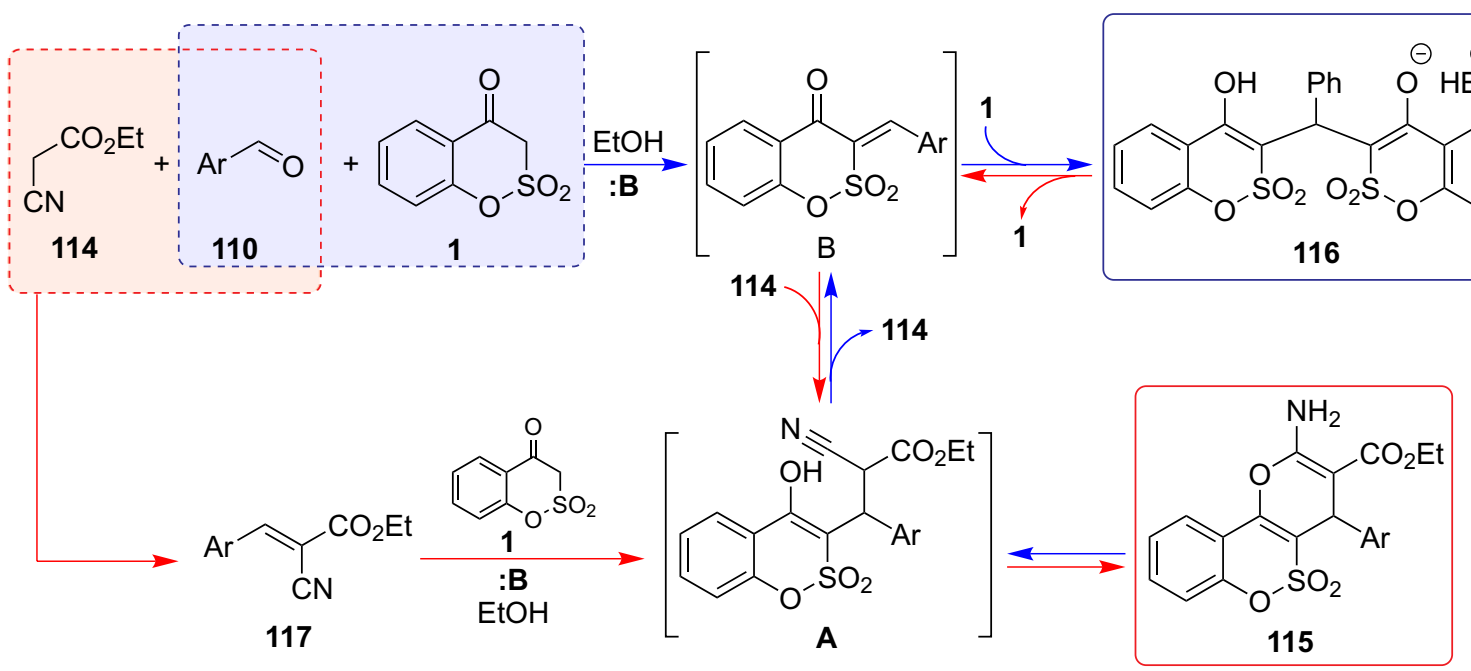

Scheme 39. The mechanism of the three-component interaction

of a high percentage of the initial benzoxathiinone $\mathbf{1}$ and ethyl $\alpha$-cyano- $\beta$-phenylacrylate (117) increasing over time (Fig. 6). Apparently, DMSO induces the retroMichael cleavage of $\mathbf{1 1 5 a}$, most probably as a result of its weak basic properties.

The use of hetarene-, cycloalkanecarbaldehydes and aliphatic aldehydes in the reaction with benzoxathiinone 1 and ethyl cyanoacetate (114) was also equivocal. In case of hetarenecarbaldehydes three different product types were isolated again depending on the aldehyde used [52]; propanal and butanal were the only aliphatic aldehydes for which ethyl 2-amino$4 H$-pyran-3-carboxylates were obtained [50]; cycloalkanecarbaldehydes gave no the target pyranes 115 [51] (Scheme 42).

Additionally, expedient two-component approaches were worked out for the synthesis of salts $\mathbf{1 1 6}$ and Hantzsch dihydropyridines 118 [47]. These routes are based on the interaction of benzoxathiinone 1 with benzaldehydes $\mathbf{1 1 0}$ in different reaction conditions (Scheme 43). It is interesting that dihydropyridine $118(\mathrm{Ar}=\mathrm{Ph})$ is also the product of the interaction between benzoxathiinone 1 and benzylidene 117 .
Apparently, ammonium salt $\mathbf{1 1 6}$ initially formed under the reaction conditions loses 2 molecules of water and cyclizes into 1,4-dihydropyridine 118.

Considering isosteric relationships of the benzoxathiine 1 core with other pharmacophores (Fig. 2), 2-amino- $4 H$-pyranes and ammonium salts presented in Schemes 37-43 were screened for the in vitro antimicrobial activity. The effect of the compounds on the blood coagulation system was also studied.

The antimicrobial activity of the compounds tested was moderate and more pronounced against grampositive bacteria than gram-negative ones and fungi [49-52].

Studies of the effect of the compounds synthesized on the blood coagulation system were performed in vitro by the Burker method (Fig. 7) [53]. The results obtained turned out to be ambiguous. Thus, studies showed that compounds $\mathbf{1 1 2 f , g}$ in the concentration of $1 \mathrm{mg} / \mathrm{mL}$ significantly increased the blood clotting time, indicating their anticoagulant properties. It should be mentioned that the anticoagulant effect was not dose-dependent as the same compounds in the concentration of $3 \mathrm{mg} / \mathrm{mL}$ showed a less

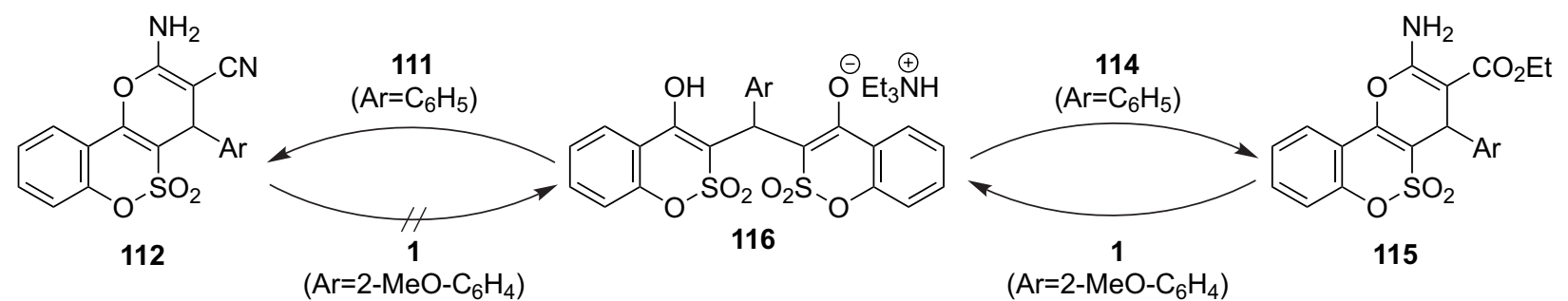

Scheme 40 . The mutual transformations of 2-amino- $4 H$-pyrans 112,115 and triethylammonium salts 116

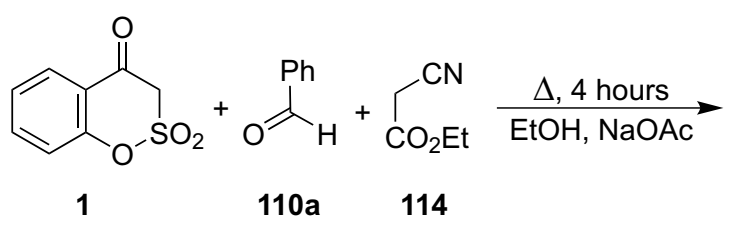<smiles>CCOC(=O)C1=C(N)Oc2c(c(=O)oc3ccccc23)C1c1ccccc1</smiles>

Scheme 41. The synthesis of ethyl 2-amino-4-phenyl-4H-pyran-3-carboxylate 115a 


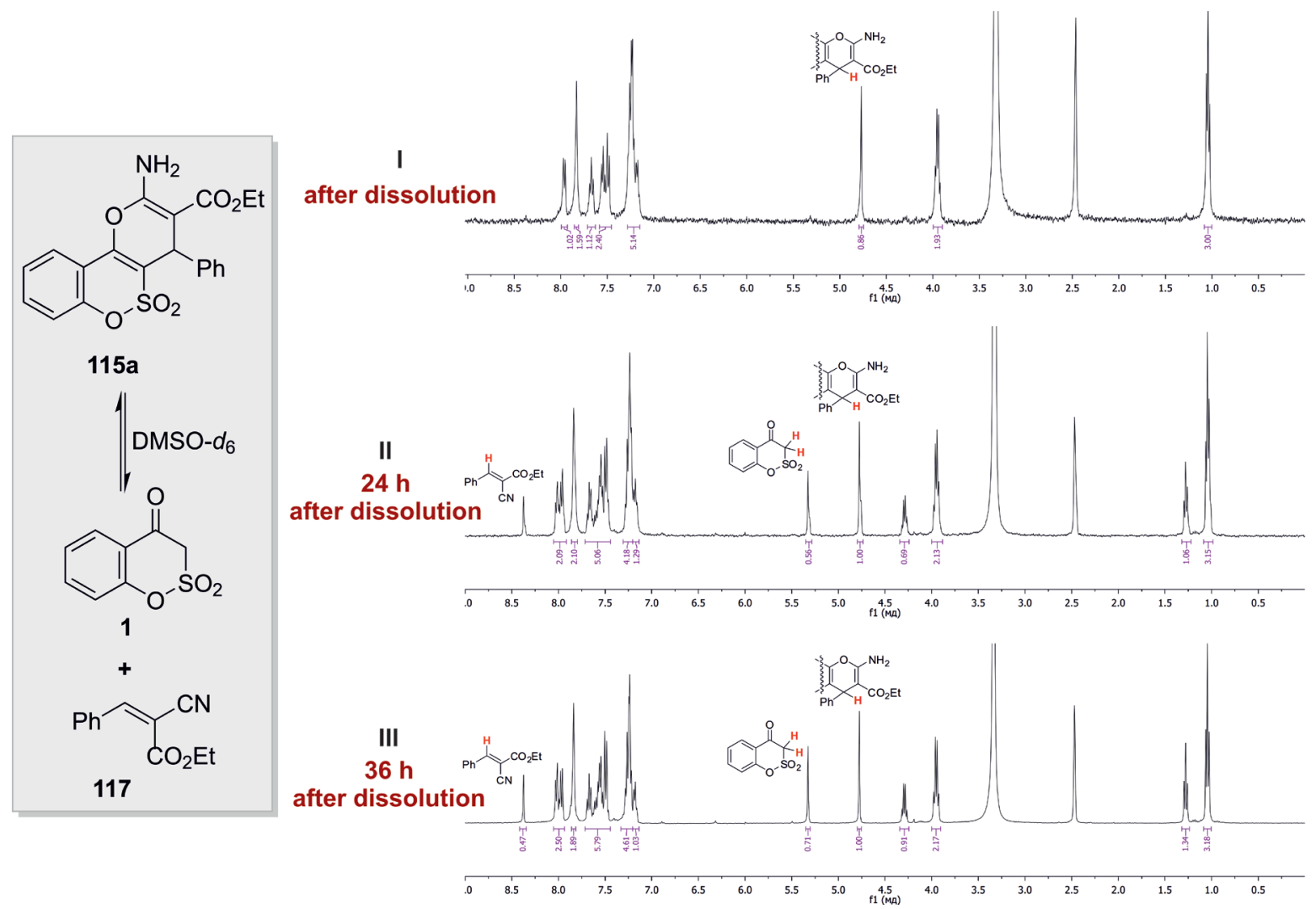

Fig. 6. The retro-Michael cleavage of ethyl 2-amino-4-phenyl-4H-pyran-3-carboxylate 115a in DMSO- $d_{6}$ solution [47]

pronounced anticoagulant effect. Hemostatic substances were also found among the compounds tested; they significantly reduced the blood clotting time compared to the control.

A series of new spiro-condensed 2-amino-4H-pyrans were synthesized by the three-component interaction of 1,2-benzoxathiin-4(3H)-one 2,2-dioxide (1), malononitrile (111), and cyclic carbonyls 119, 120 in moderate to high yields (Scheme 44) [48]. When ethyl cyanoacetate (114) was used, the target ethyl
2-amino-4H-pyran-3-carboxylate was obtained only for N-ethylisatin. Variations in catalysts, solvents and heating modes did not affect the efficiency of this interaction.

The spiro-derivatives synthesized were studied for the anti-inflammatory and analgesic activities [49] According to the results obtained the compounds were much more promising analgesic agents than anti-inflammatory ones. The level of anti-inflammatory activity was significantly lower than for Piroxicam (Fig. 8),

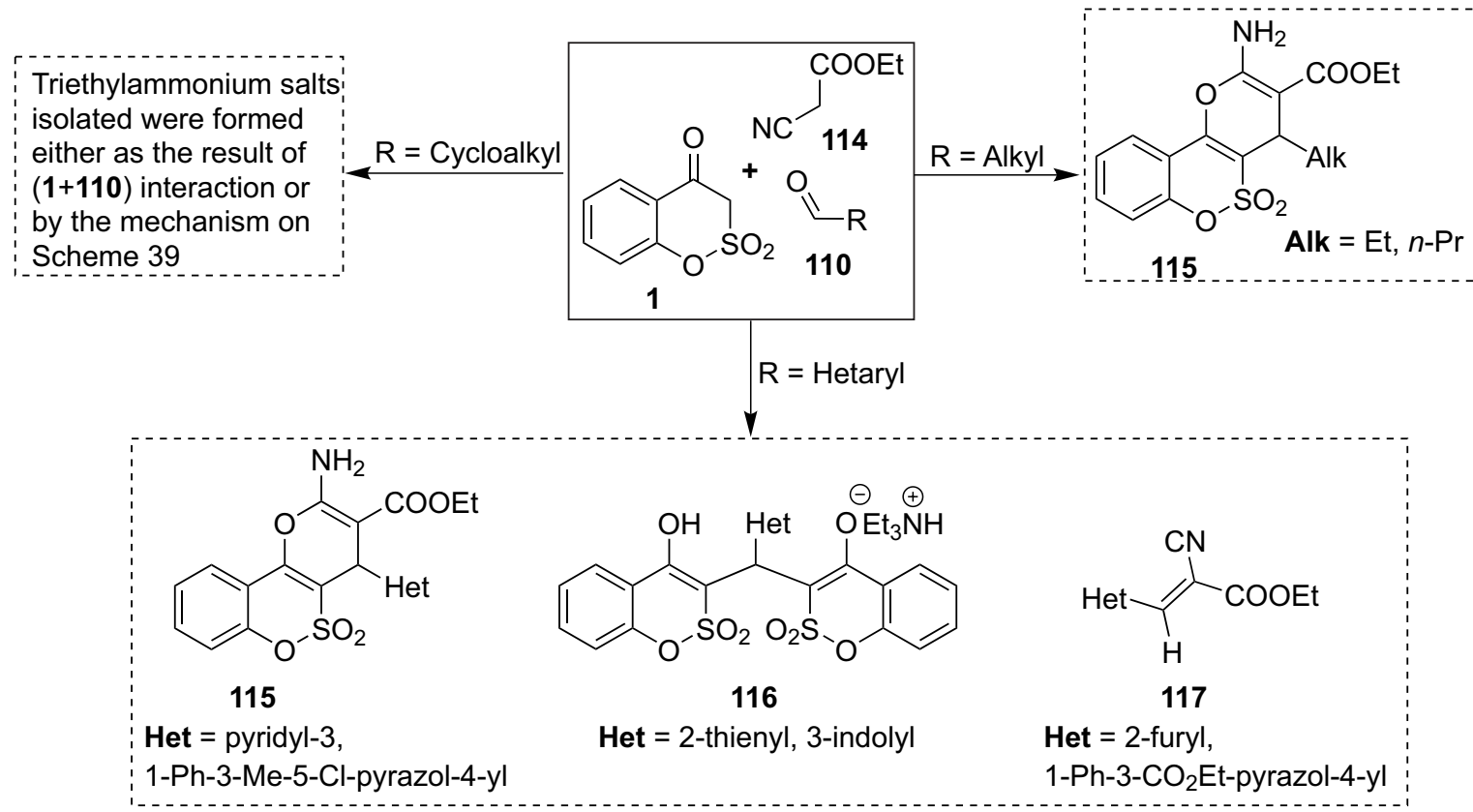

Scheme 42. The use of hetarene-, cycloalkanecarbaldehydes and aliphatic aldehydes in the reaction with benzoxathiinone 1 and ethyl cyanoacetate (114) 


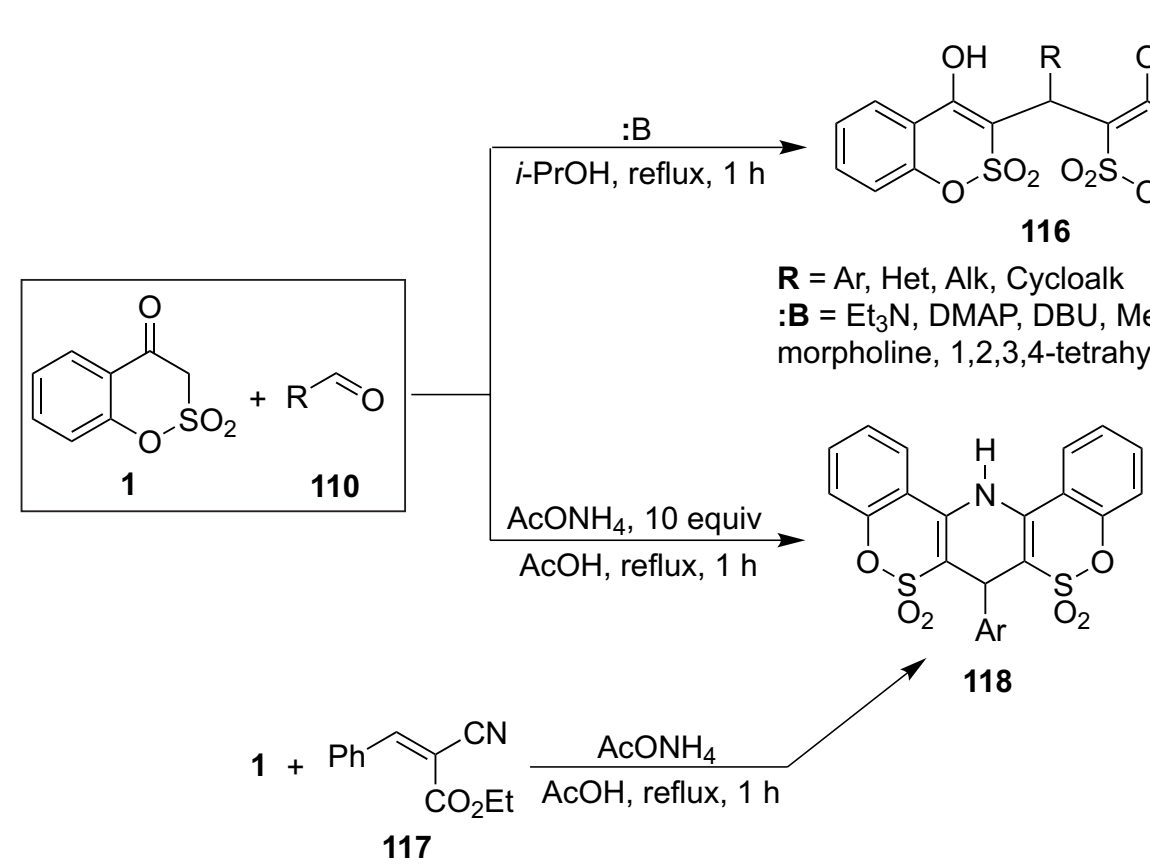

Scheme 43. The synthesis of ammonium salts 116 and Hantzsch dihydropyridines 118

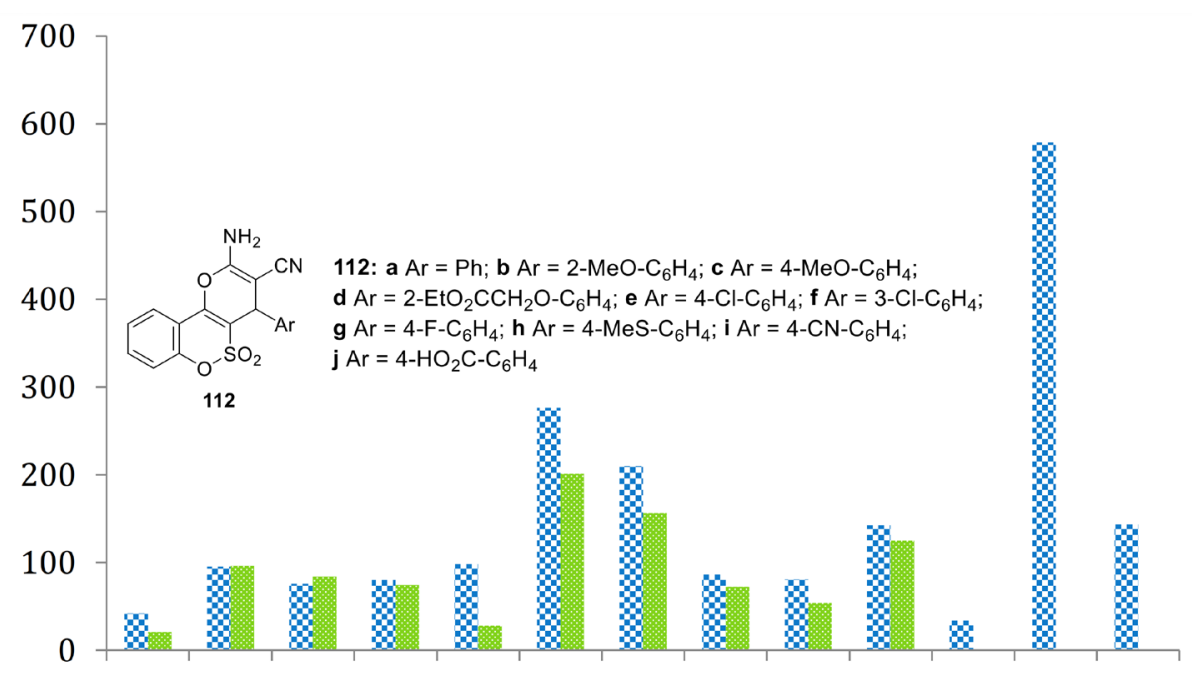

112a 112b 112c 112f 112h 112j 112k 112p 112q 112r AA Hep Contr

s $1 \mathrm{mg} / \mathrm{mL}$ 䒽 $3 \mathrm{mg} / \mathrm{mL} \quad \mathrm{AA}$ - aminocaproic acid Hep-heparin Contr-control

Fig. 7. The anticoagulant properties of 2-amino-4H-pyran-3-carbonitriles 112

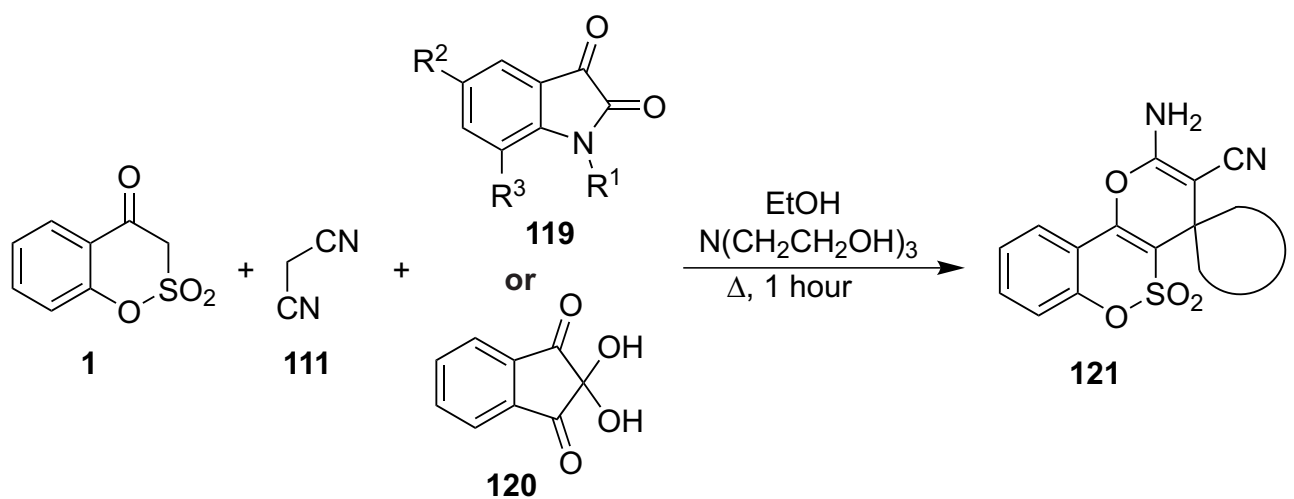

Scheme 44. The synthesis of spiro-condensed 2-amino-4H-pyrans 


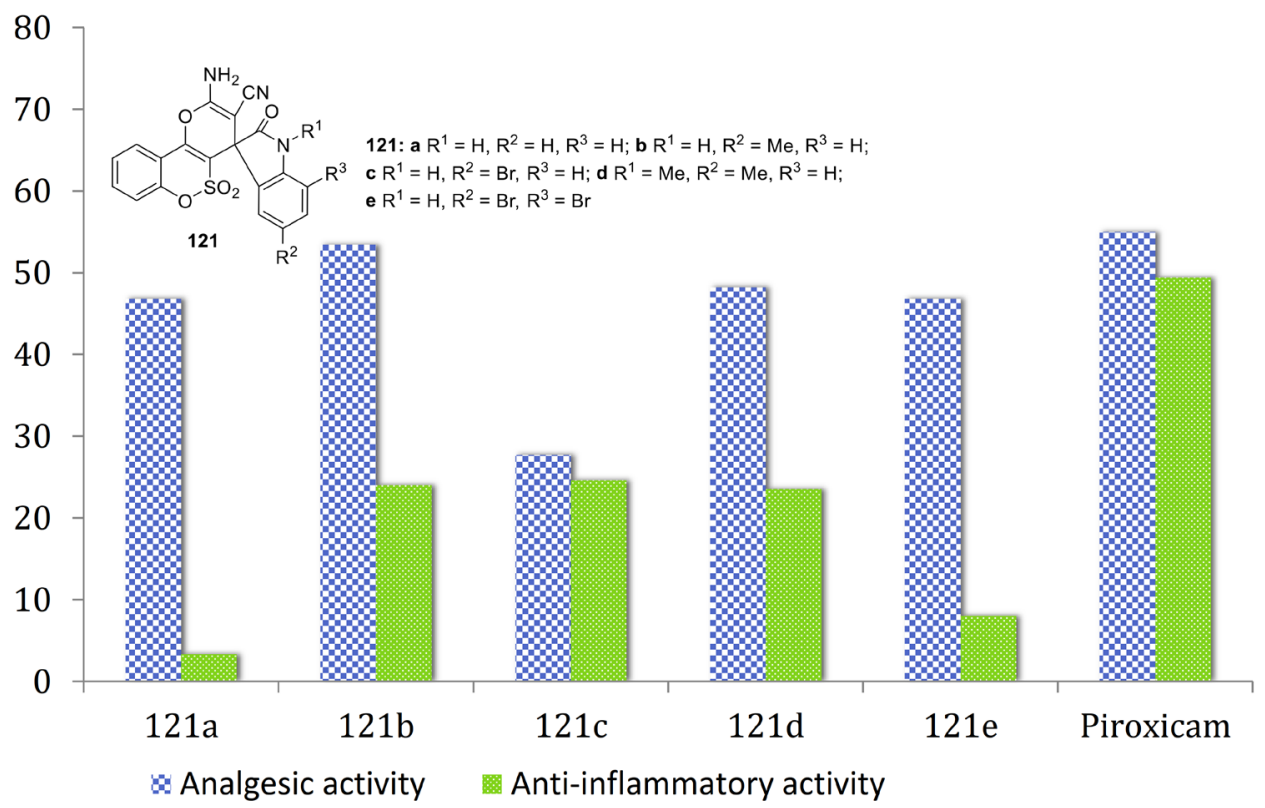

Fig. 8. The anti-inflammatory and analgesic activity of 2-amino-4H-pyran-3-carbonitriles 121

whereas the analgesic activity of the test substances was about the activity of the reference drug.

\section{Conclusions}

The analysis has shown a limited number of studies in each aspect - approaches to the synthesis of 1,2-benzoxathiin-4(3H)-one 2,2-dioxides, their chemical transformations and the study of their pharmacological activity. In addition to a small number of publications on this heterocyclic system, there have been almost no sultone studies in the last 20 years. Taking this into account 1,2-benzoxathiin-4(3H)-one 2,2-dioxide and its derivatives deserve close attention as objects of research for experimental chemistry and pharmacology.

Conflict of interests: the authors have no conflict of interests to declare.

\section{References}

1. Markitanov, Y. M.; Timoshenko, V. M.; Shermolovich, Y. G. $\beta$-Keto sulfones: preparation and application in organic synthesis. Journal of Sulfur Chemistry 2014, 35 (2), 188-236. https://doi.org/10.1080/17415993.2013.815749.

2. Roberts, D. W. Sulfonation Technology for Anionic Surfactant Manufacture. Org. Process Res. Dev. 1998, 2 (3), 194-202. https://doi.org/10.1021/ op9700439.

3. De Castro, S.; García-Aparicio, C.; Andrei, G.; Snoeck, R.; Balzarini, J.; Camarasa, M.-J.; Velázquez, S. 4-Benzyloxy- $\gamma$-Sultone Derivatives: Discovery of a Novel Family of Non-Nucleoside Inhibitors of Human Cytomegalovirus and Varicella Zoster Virus. J. Med. Chem. 2009, 52 (6), 1582-1591. https://doi.org/10.1021/jm8014662.

4. de Castro, S.; Lobatón, E.; Pérez-Pérez, M.-J.; San-Félix, A.; Cordeiro, A.; Andrei, G.; Snoeck, R.; De Clercq, E.; Balzarini, J.; Camarasa, M.-J.; Velázquez, S. Novel [2',5'-Bis-O-(tert-butyldimethylsilyl)- $\beta$-d-ribofuranosyl]-3'-spiro-5"'-(4"'-amino-1",2"-oxathiole-2",2"-dioxide) Derivatives with Anti-HIV-1 and Anti-Human-Cytomegalovirus Activity. J. Med. Chem. 2005, 48 (4), 1158-1168. https://doi.org/10.1021/jm040868q.

5. Xu, Y.; Zhang, Z.; Shi, J.; Liu, X.; Tang, W. Recent developments of synthesis and biological activity of sultone scaffolds in medicinal chemistry. Arabian Journal of Chemistry 2021, 14 (4), 103037. https://doi.org/10.1016/j.arabjc.2021.103037.

6. Mondal, S. Recent Developments in the Synthesis and Application of Sultones. Chem. Rev. 2012, 112 (10), 5339-5355. https://doi.org/10.1021/ cr2003294.

7. Ali, G.; Subhan, F.; Khan, I.; Islam, N. U. Input of Isosteric and Bioisosteric Approach in Drug Design. J. Chem. Soc. Pak. 2014, 36 (1), $150-169$.

8. Thornber, C. W. Isosterism and molecular modification in drug design. Chem. Soc. Rev. 1979, 8 (4), 563-580. https://doi.org/10.1039/CS9790800563.

9. Au, N.; Rettie, A. E. Pharmacogenomics of 4-Hydroxycoumarin Anticoagulants. Drug Metabolism Reviews 2008, 40 (2), 355-375. https://doi.org/ $10.1080 / 03602530801952187$.

10. Ukrainets, I. V.; Petrushova, L. A.; Dzyubenko, S. P.; Sim, G. 2,1-Benzothiazine 2,2-Dioxides. 3*. 4-Hydroxy-1-Methyl-2,2-Dioxo-N-(1,3-Thiazol-2-

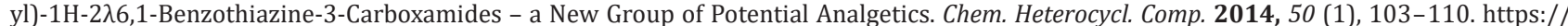
doi.org/10.1007/s10593-014-1452-0.

11. Lega, D. A.; Filimonova, N. I. Zupanets, I. A.; Shebeko, S. K.; Chernykh, V. P.; Shemchuk, L. A. Synthesis, anti-inflammatory, analgesic and antimicrobial activities of ethyl 2-amino-4-alkyl-4,6-dihydropyrano[3,2-c][2,1]benzothiazin-3-carboxylate 5,5-dioxides and triethylammoniun 3-[(4-hydroxy1-ethyl-2,2-dioxido-1 H-2,1-benzothiazin-3-yl)alkyl]-1-ethyl-1 H-2,1-benzothiazin-5-olat 2,2-dioxides. Journal of Organic and Pharmaceutical Chemistry 2016, 14 (4), 3-11. https://doi.org/10.24959/ophcj.16.900.

12. Majumdar, K. C.; Mondal, S.; Ghosh, D. Synthesis of tricyclic and tetracyclic sultones by Pd-catalyzed intramolecular cyclization. Tetrahedron Lett. 2009, 50 (33), 4781-4784. https://doi.org/10.1016/j.tetlet.2009.06.028.

13. Metz, P.; Fleischer, M. Intramolecular Diels-Alder Reaction of Vinylsulfonates Possessing an Acyclic Diene Moiety. Synlett 1993, 1993 (06), 399-400. https://doi.org/10.1055/s-1993-22469.

14. Karsch, S.; Freitag, D.; Schwab, P.; Metz, P. Ring Closing Metathesis in the Synthesis of Sultones and Sultams. Synthesis 2004, 2004 (10), 1696-1712. https://doi.org/10.1055/s-2004-822408.

15. Karsch, S.; Schwab, P.; Metz, P. Synthesis of Sultones by Ring Closing Metathesis. Synlett 2002, 2002 (12), 2019-2022. https://doi.org/ 10.1055/s-2002-35560. 
16. John, J. P.; Novikov, A. V. Selective Formation of Six-Membered Cyclic Sulfones and Sulfonates by C-H Insertion. Org. Lett. 2007, 9 (1), 61-63. https://doi.org/10.1021/ol062592h.

17. Wolckenhauer, S. A.; Devlin, A. S.; Du Bois, J. $\delta$-Sultone Formation Through Rh-Catalyzed C-H Insertion. Org. Lett. 2007, 9 (21), $4363-4366$. https://doi.org/10.1021/ol701950d.

18. Uno, H.; Kurokawa, M. Studies on 3-Substituted 1, 2-Benzisoxazole Derivatives. VII. Catalytic Reduction of 3-Sulfamoylmethyl-1, 2-benzisoxazole and Reactions of the Resulting Products. Chem. Pharm. Bull. 1982, 30 (1), 333-335. https://doi.org/10.1248/cpb.30.333.

19. King, L. C.; Ostrum, G. K. Selective Bromination with Copper(II) Bromide. J. Org. Chem. 1964, 29 (12), 3459-3461. https://doi.org/10.1021/ jo01035a003.

20. Barbieri, W.; Bernardi, L.; Coda, S.; Vigevani, A. Synthesis and reactions of 1,2-benzoxathian-4-one 2-oxides. Tetrahedron Lett. 1971, 12 (52), 4913-4914. https://doi.org/10.1016/S0040-4039(01)97587-2.

21. Meyer, R. F. Some novel cyclizations of propiophenones with chlorosulfonic acid. J. Heterocycl. Chem. 1966, 3 (2), 174-177. https://doi.org/ $10.1002 /$ jhet.5570030213.

22. Claney, J.; Alice, G.; Timoney, R. Int. J. Sulfur Chem., Part A. 1972, 2, 249-255.

23. Rehse, K.; Tenczer, J. Gerinnungsphysiologische Aktivität von 1,2-Benzoxathiinen. Arch. Pharm. 1980, 313 (3), 249-254. https://doi.org/ 10.1002/ardp.19803130310.

24. Grandane, A.; Belyakov, S.; Trapencieris, P.; Zalubovskis, R. Facile synthesis of coumarin bioisosteres-1,2-benzoxathiine 2,2-dioxides. Tetrahedron 2012, 68 (27), 5541-5546. https://doi.org/10.1016/j.tet.2012.04.080.

25. Grandane, A.; Tanc, M.; Zalubovskis, R.; Supuran, C. T. 6-Triazolyl-substituted sulfocoumarins are potent, selective inhibitors of the tumor-associated carbonic anhydrases IX and XII. Bioorg. Med. Chem. Lett. 2014, 24 (5), 1256-1260. https://doi.org/10.1016/j.bmcl.2014.01.076.

26. Grandane, A.; Tanc, M.; Di Cesare Mannelli, L.; Carta, F.; Ghelardini, C.; Žalubovskis, R.; Supuran, C. T. 6-Substituted Sulfocoumarins Are Selective Carbonic Anhdydrase IX and XII Inhibitors with Significant Cytotoxicity against Colorectal Cancer Cells. J. Med. Chem. 2015, 58 (9), 3975 -3983. http://doi.org/10.1021/acs.jmedchem.5b00523.

27. Grandane, A.; Tanc, M.; Žalubovskis, R.; Supuran, C. T. Synthesis of 6-aryl-substituted sulfocoumarins and investigation of their carbonic anhydrase inhibitory action. Bioorg. Med. Chem. 2015, 23 (7), 1430-1436. https://doi.org/10.1016/j.bmc.2015.02.023.

28. Schwender, Ch. F.; Sunday, B. R. 1,2-Benzoxathiin-2,2-dioxides. US4116961A, Sep 26, 1978.

29. Cecchetti, V.; Fravolini, A.; Fringuelli, R.; Schiaffella, F. New Heterocyclic Ring System. XIV. 7,11-Dithiaoxasteroids Analogues. Heterocycles 1984, 22 (10), 2293-2300. https://doi.org/10.3987/R-1984-10-2293.

30. Arava, V. R.; Siripalli, U. B. R.; Nadkarni, V.; Chinnapillai, R. Beilstein J. Org. Chem. 2007, 3 (20). https://doi.org/10.1186/1860-5397-3-20.

31. Allegrini, P.; Bologna, A.; Castaldi, G.; Lucchini, V.; Mantegazza, S.; Razzetti, G. Process for the preparation of benzo[d]isoxazol-3-yl-methanesulfonic acid and the intermediates thereof. US20080081914A1, Apr 03, 2008.

32. Peixoto, C.; Laurin, P.; Klich, M.; Dupuis-Hamelin, C.; Mauvais, P.; Lassaigne, P.; Bonnefoy, A.; Musicki, B. Synthesis of isothiochroman 2,2-dioxide and 1,2-benzooxathiin 2,2-dioxide gyrase B inhibitors. Tetrahedron Lett. 2000, 41 (11), 1741-1745. https://doi.org/10.1016/S0040-4039(00)00044-7.

33. Löwe, W.; Müller-Menke, C. Notiz zur Synthese von 1,2-Benzoxathiin-2,2-dioxid-Derivaten aus 3-Chromonsulfonsäure. Liebigs Ann. Chem. 1984, 1984 (7), 1395-1397. https://doi.org/10.1002/jlac.198419840716.

34. Löwe, W.; Matzanke, N.; Rütjes, T. Synthesen von Chromon-3-sulfonylharnstoffen. Arch. Pharm. 1994, 327 (12), 819-823. https://doi.org/ $10.1002 / \operatorname{ardp} .19943271213$.

35. Löwe, W.; Jeske, P. 3,4-Dihydro-6-methyl-1,2-benzoxathiin-2,2-dioxid-Derivate mit Enaminketon-Strukturen aus 6-Methyl-4-chromon-3-sulfonsäure-phenylester. Liebigs Ann. Chem. 1985, 1985 (10), 2012-2016. https://doi.org/10.1002/jlac.198519851009.

36. Löwe, W.; Jeske, P. Umsetzungen von 4-Chromon-3-sulfonsäure-phenylester mit Amidinen. Liebigs Ann. Chem. 1986, 1986 (6), $1124-1126$. https://doi.org/10.1002/jlac.198619860617.

37. Löwe, W.; Braden, T. Umsetzung von aromatischen Enaminonen mit Chlorsulfonsäure. Arch. Pharm. 1991, 324 (6), 385-387. https://doi.org/ 10.1002/ardp.19913240614.

38. Ghandi, M.; Bozcheloei, A. H.; Nazari, S. H.; Sadeghzadeh, M. Solvent-Dependent Reactions for the Synthesis of $\beta$-Keto-Benzo- $\delta$-Sultone Scaffolds via DBU-Catalyzed O-Sulfonylation/Intramolecular Baylis-Hillman/1,3-H Shift or Dehydration Tandem Sequences. J. Org. Chem. 2011, 76 (24), 9975-9982. http://doi.org/10.1021/jo201506d.

39. Ghandi, M.; Taghi Nazeri, M.; Kubicki, M. An efficient one-pot, regio- and stereoselective synthesis of novel pentacyclic-fused pyrano[3,2-c]chromenone or quinolinone benzosultone derivatives in water. Tetrahedron 2013, 69 (24), 4979-4989. https://doi.org/10.1016/j.tet.2013.04.018.

40. Li, B.; Yan, W.; Zhang, C.; Zhang, Y.; Liang, M.; Chu, F.; Gong, Y.; Xu, B.; Wang, P.; Lei, H. New Synthesis Method for Sultone Derivatives: Synthesis, Crystal Structure and Biological Evaluation of S-CA. Molecules 2015, 20 (3), 4307-4318. https://doi.org/10.3390/molecules20034307.

41. Löwe, W.; Müller-Menke, C. Reaktionen des 4-Hydroxy-1,2-benzoxathiin-3-carbaldehyd-2,2-dioxids mit Aminen und Hydrazinen. Arch. Pharm. 1988, 321 (10), 755-756. https://doi.org/10.1002/ardp.19883211013.

42. Löwe, W.; Müller-Menke, C. 1,2-Benzoxathiino[4,3-d]pyrimidin-5,5-dioxide. Arch. Pharm. 1985, 318 (10), 954-956. https://doi.org/10.1002/ ardp.19853181019.

43. Löwe, W.; Jeske, P.; Kradepohl, A. An unusual ring transformation: Reaction of phenyl 4-chromone-3-sulfonate with methyl 3-aminocrotonate. J. Heterocycl. Chem. 1988, 25 (2), 699-701. https://doi.org/10.1002/jhet.5570250263.

44. Löwe, W.; Kradepohl, A. Michael additions with an enaminoester: Reaction of phenyl 4-chromone-3-sulfonate with methyl 3-amino-2-pentenoate. J. Heterocycl. Chem. 1989, 26 (3), 753-756. https://doi.org/10.1002/jhet.5570260345.

45. Löwe, W.; Kradepohl, A. 1,2- und 1,4-Additionen methylen-aktiver Verbindungen an ein heterocyclisches Enaminon. Arch. Pharm. 1990, 323 (12), 987-989. https://doi.org/10.1002/ardp.19903231209.

46. Löwe, W.; Göbel, S.; Müller-Menke, C. Über eine Benzoxathiin-Chromon-Ringtransformation. Arch. Pharm. 1988, 321 (10), 729-730. https://doi.org/ 10.1002/ardp.19883211006.

47. Grygoriv, G. V.; Lega, D. A.; Chernykh, V. P.; Zaprutko, L.; Gzella, A. K.; Pawełczyk, A.; Shemchuk, L. A. 1,2-Benzoxathiin-4(3H)-one 2,2-dioxide new enol nucleophile in three-component interaction with benzaldehydes and active methylene nitriles. RSC Adv. 2018, 8, 37295-37302. https://doi.org/10.1039/c8ra06801a.

48. Grygoriv, G. V.; Lega, D. A.; Zaprutko, L.; Gzella, A. K.; Wieczorek-Dziurla, E.; Chernykh, V. P.; Shemchuk, L. A. Synthesis of novel spiro-condensed 2-amino-4H-pyrans based on 1,2-benzoxathiin-4(3H)-one 2,2-dioxide. Chem. Heterocycl. Comp. 2019, 55 (3), 254-260. https://doi.org/ 10.1007/s10593-019-02450-4.

49. Grygoriv, G. V.; Lega, D. A.; Zupanets, I. A.; Shebeko, S. K.; Zimin, S. M.; Starchikova, I. L.; Shemchuk, L. A. Spiro[benzo[e]pyrano[3,2-c][1,2] oxathiin-4,3'-indolil]-3-carbonitrile 5,5-dioxides: synthesis and the biological activity study. Journal of Organic and Pharmaceutical Chemistry 2019, 17 (4), 53-61. https://doi.org/10.24959/ophcj.19.182954. 
50. Grygoriv, G. V.; Lega, D. O.; Chernykh, V. P.; Osolodchenko, T. P.; Shemchuk, L. A. Synthesis of 1,2-benzoxathiine 2,2-dioxide derivatives using aliphatic aldehydes and assessment of their antimicrobial activity. Journal of Organic and Pharmaceutical Chemistry 2017, 15 (4), 33-10. https:// doi.org/10.24959/ophcj.17.927.

51. Grygoriv, G.; Lega, D.; Chernykh, V.; Osolodchenko, T.; Shemchuk L. Cycloalkanecarbaldehydes in synthesis of novel 1,2-benzoxathiin4(3H)-one 2,2-dioxide derivatives and study of the antimicrobial activity of synthesized compounds. ScienceRise: Pharmaceutical Science 2017, 6, 4-10. https://doi.org/10.15587/2519-4852.2017.119279.

52. Grygoriv, G. V.; Lega, D. A.; Chernykh, V. P.; Osolodchenko, T. P.; Shemchuk L. A. Domino-reactions of 1,2-benzoxathiin-4(3H)-one 2,2-dioxide, hetarenecarbaldehydes and active methylene nitriles in the construction of new 2-amino-4H-pyrans and investigation of their antimicrobial properties. Journal of Organic and Pharmaceutical Chemistry 2018, 16 (1), 3-10. https://doi.org/10.24959/ophcj.18.931.

53. Grygoriv, G. V.; Lega, D. A.; Shemchuk, L. M.; Maloshtan, L. M.; Kalenichenko, G. S.; Chernykh, V. P.; Shemchuk, L. A. The synthesis of 2-amino4-aryl-4H-pyrano[3,2-c][1,2] benzoxathiine-3-carbonitrile 5,5-dioxides and the study of their effect on the blood coagulation process. News of Pharmacy 2018, 4, 3-8. https://doi.org/10.24959/nphj.18.2224.

54. Lega, D. A.; Gorobets, N. Y.; Chernykh, V. P.; Shishkina, S. V.; Shemchuk, L. A. Peculiarities of 2-amino-3-R-4-aryl-4H-pyranes multicomponent synthesis derived from 1H-2,1-benzothiazin-4(3H)-one 2,2-dioxide. RSC Adv. 2016, 6 (19), 16087-16099. https://doi.org/10.1039/c5ra24566d.

55. Lega, D. A.; Chernykh, V. P.; Shemchuk, L. A. The study of three-component interaction between 1-ethyl-1H-2,1-benzothiazin-4(3H)-one 2,2-dioxide, heterylcarbaldehydes and active methylene nitriles. Journal of Organic and Pharmaceutical Chemistry 2016, 14 (1), 6-16. https://doi.org/ 10.24959/ophcj.16.876.

Received: 12.05. 2021

Revised: 02.06. 2021

Accepted: 05. 06. 2021

The work is a part of researches of the National University of Pharmacy on the topic «Organic synthesis and analysis of biologically active compounds, drugs development on the basis of synthetic substances» (the state registration No. 01144000943;

the research period 2019-2024) 